\title{
THE RIGHTS OF A WITNESS BEFORE A GRAND JURY
}

The implications of recent decisions of the Supreme Court which have given new and expanded meanings to the procedural safeguards owing to a criminal defendant have not yet been fully realized. Most immediately, they will undoubtedly affect established practices of law enforcement agencies. An important consequence of these changes, however, may also be the extension of the right to counsel to the grand jury witness.

$\mathrm{R}$

ECENT decisions of the Supreme Court fortifying and expanding the constitutional rights of criminal defendants have thrown much doubt upon the validity of existing governmental practices designed to execute the criminal law. While the scope and impact of decisions interpreting the fourth, fifth, and sixth amendments are not entirely clear, an analysis of the operations of the grand jury would indicate that witnesses before that body may well benefit from developments in analogous areas of the law. It is, therefore, the purpose of this comment to outline the established rights of witnesses who are summoned before state and federal grand juries and to examine the factors promoting an expansion of those existing rights in light of the characteristics and policy foundations of grand jury procedure.

\section{BACRGROUND}

\section{A. Status of the Institution}

As a preliminary step to a consideration of the rights of grand jury witnesses, it is important to summarize the present status, the purpose, and the peculiar characteristics of the grand jury in relation to the entire criminal process. The fifth amendment to the Constitution has been interpreted to provide that the criminally accused in a federal prosecution has the right to an indictment or presentment ${ }^{1}$

${ }^{1}$ While the independent grand jury through its power of presentment is still considered by some proponents as a valuable potential restraint on corruption, e.g., Younger, The People's Panel: The Grand JuRY IN THE United States, 1634-1941, at 245 (1963), the presentment device has become largely anachronistic. The Advisory Committee has explained the absence of any mention of presentment in the Federal Rules of Criminal Procedure by noting that "presentment is not included as an additional type of formal accusation, since presentments as a method of instituting prosecu. tions are obsolete, at least as concerns the Federal courts." Advisory Commitee's Note, 18 U.S.C. APP, at 3746 (1964). 
by a grand jury if a conviction of the crime with which he is charged could result in an "infamous" punishment." The guarantee of the grand jury, however, is personal to the accused and, like other constitutional guarantees, may be waived. ${ }^{3}$

In contrast to the federal government, the states are not required by the Constitution to initiate criminal prosecutions with a grand jury proceeding." In Hurtado v. California, victed of a capital offense in a state court, argued that the due process clause of the fourteenth amendment compelled the states to proceed by indictment or presentment in the prosecution of infamous crimes. ${ }^{6}$ The Supreme Court affirmed the conviction and, in doing so, rejected the due process argument. The Court held that the fourteenth amendment did not preclude experimentation by im-

"The "infamous" punishment conception has been developed in a long line of Supreme Court decisions construing the fifth amendment. It has been held that con. finement at hard labor, United States v. Moreland, 258 U.S. 433 (1922); or in a penitentiary, Mackin v. United States, 117 U.S. 348 (1886); Ex parte Wilson, 114 U.S. 417, 429 (1885); or punishment for more than one year, Barkman v. Sanford, 162 F.2d 592 (5th Cir.) (dictum), cert. denied, 332 U.S. 816 (1947), are infamous punishments. The Federal Rules have codified these holdings in the following provision: "An offense which may be punished by death shall be prosecuted by indictment. An offense which may be punished by imprisonment for a term exceeding one year or at hard labor shall he prosecuted by indictment, or if indictment is waived, it may be prosecuted by in. formation. Any other offense may be prosecuted hy indictment or information." FED. R. CRIM. P. 7 (a).

However, because "infamous punishment" is a functional concept, the criteria for which may change according to "public opinion from one age to another," Ex parte Wilson, supra at 127, the scope of the grand jury guarantee is always subject to enlargement. See generally Orfield, The Federal Grand Jury, 22 F.R.D. 343, 359.60 (1959); Annot., 2 L. Ed. 2d 1960 (1958).

${ }^{3}$ Barkman v. Sanford, 162 F.2d 592, 593 (5th Cir.), cert. denied, 332 U.S. 816 (1947). FED. R. CRIM. P. 7 (b) permits waiver of indictment except where the imposition of capital punishment could result from conviction. In tbe interests of avoiding the delay encountered in awaiting indictment, most defendants consent to accusation by information. See Bartlett v. United States, 354 F.2d 745, 749-50 (8th Cir. 1966).

4Similarly, territories of the United States are not constitutionally required to use the presentment or indictment. Hawaii v. Mankichi, 190 U.S. 197 (1903).

$\checkmark 110$ U.S. 516 (1884).

- According to the Court, the defendant argued that "the phrase 'due process of the law' is equivalent to 'law of the land,' as found in the 29th chapter of Magna Charta; that by immemorial usage it has acquired a fixed, definite, and technical meaning ...." Id. at 521 . Consequently, "any proceeding otherwise authorized by law, which is not thus sanctioned by usage, or which supersedes and displaces one that is, cannot he regarded as due process of the law." Id. at 528. To this rather sweeping contention the Court replied: "But to hold that such a characteristic is essential to due process of law, would be to deny every quality of the law but its age, and to render it incapable of progress or improvement. It would be to stamp upon our jurisprudence the unchangeableness attributed to the laws of the Medes and Persians." Id. at 529. 
posing immutable requirements of federal criminal procedure on the states. Moreover, in reasoning that would today appear unsound, it indicated that due process could not encompass rights which were conjunctively guaranteed by the fifth amendment. ${ }^{7}$ On the basis of the sanction afforded by Hurtado, some states have replaced the grand jury indictment or presentment with accusation by information for at least some prosecutions, while other jurisdictions have found the historic institution well suited to modern exigencies and consequently have retained it. ${ }^{8}$

\section{B. Purposes of the Grand Jury}

The grand jury has served two significant but potentially inconsistent purposes in the criminal proceeding. ${ }^{9}$ It has functioned both as a body of accusers and as a protector of the citizen from unfounded accusations.10 At its inception, the grand jury found its primary raison d'etre in fulfilling its role as accuser. ${ }^{11}$ Later, however, with

The Court reasoned that the inclusion of the due process guarantee in the fifth amendment in conjunction with the rights of self-incrimination, double jeopardy, and grand jury action rendered these rights mutually exclusive. To the Court, therefore, the due process clause of the fourteenth amendment could not logically impose the mandatory recognition of the rights of self-incrimination, double jeopardy, or grand jury action on the states. 110 U.S. at 534. Implicit in Malloy v. Hogan, 378 U.S. 1 (1964) (incorporating the privilege against self-incrimination into the fourteenth amendment's due process clause) is a necessary rejection of this reasoning. See id. at 20-22 (Harlan, J., dissenting).

In addition to relying on a presently discarded constitutional construction, the Court in Hurtado was true to the nineteenth century evolutionary Weltanschauung in its appraisal of the underlying public policy to be promoted. The policy argument in question was succinctly articulated by the Wisconsin Supreme Court some years before the Hurtado decision: "Administration and remedial proceedings must change from time to time with the advancement of legal science and the progress of society ...." Rowan v. State, 30 Wis. 129, 149 (1872).

It would appear to follow that the Hurtado reasoning to the effect that due process does not refer to certain specific procedural aspects of a criminal prosecution can no longer be accepted. Therefore, the question of the states' obligation to adopt the grand jury as a requirement of due process is subject to reevaluation in the light of contemporary standards. See Malloy v. Hogan, supra at 4 n.2, 5. But see State v. Kanistanaux, 414 P.2d 784 (Wash. 1966).

${ }^{8}$ See Scigliano, The Grand Jury, the Information, and the Judicial Inquiry, 38 Ore. L. REv. 303, 305 (1959); Spain, The Grand Jury, Past and Present: A Suruey, 2 AMERICAN CRIM. L.Q. 119, 126-42 (1964).

- Orfield, Criminal Procedure from Arrest to Appeal 144-46 (1947) [hereinafter cited as Orfielo]; Orfield, supra note 2, at 394.

${ }^{10}$ See Hurtado v. California, 110 U.S. 516, 556 (1884) (Harlan, J., dissenting). A possible third purpose of the grand jury was to inject further technicalities into the criminal law as an early revolt from the severity of its consequences.

${ }^{11}$ See id. at 530; EDwards, THE GRAND JURY $21-25$ (1906) [hereinafter cited as EdWARDS]; ORFIELD 138-39. 
the development of the petit jury and the adoption of the accusatorial criminal trial, ${ }^{12}$ the grand jury's most important function became the task of standing "steadfast between the crown and the people in the defense of the liberty of the citizen."13 Even today the accusatorial function clearly predominates when the grand jury acts on its own initiative by proffering presentments. ${ }^{14}$ However, where the government initiates the inquisition by drawing an indictment on which the grand jury is directed to act, the accusatorial role is clearly subordinate to the protective one. ${ }^{15}$

Considered in the light of its history in American law, the more important of the grand jury's two roles would appear to be its protective function. In addition to the fact that, at the time the institution was enshrined in the Constitution, English law stressed the protective feature, ${ }^{16}$ the placement of the grand jury guarantee in our

${ }^{12}$ See EDWARDS 26-28; OrfiEId 139.

18 EDwards 27.

16 Since the presentment originates with the grand jury and is a result of its independent probing, it is evident that in this instance, the positive, accusatorial aspect is predominant. Note in this regard, however, that the Advisory Committee for the Federal Rules of Criminal Procedure considers the presentment obsolete. See note 1 supra. See also McNair's Petition, 324 Pa. 48, 187 Atl. 498 (1936) (recognizing that the power of presentment does not obtain in Pennsylvania); N.C. GEN. Stat. \$15-137 (1953) (abolishing the presentment).

15 Where the prosecutor brings an indictment the grand jury screens his case to protect the accused from facing trial where the evidence is insufficient to make out a prima facie case.

Acceptance of the position that the central purpose of the grand jury is protective has prompted the conclusion that the test for sufficiency of evidence for an indictment should be based on "susceptibility to conviction," that is, "if nothing more were heard at trial, a petit jury could conclude that the prosecution had successfully borne the burden of proof." Note, 72 YALE L.J. 590, 592 (1963). State statutes setting forth the proof requisite for returning a true bill most frequently express the test in terms similar to ARk. STAT. ANN. \$43-920 (1947): "The grand jury should find an indictment when all the evidence before them, taken together, would, in their judgment, if unexplained, warrant a conviction by the trial jury." E.g., CAL. PEN. CODE $\$ 939.8$; IOWA CODE §771.16 (1962); MONT. REv. CODEs ANN. \$94-6320 (1947). But see ARtz. R. CRIM. P. 103; KY. R. CRIM. P. 5.10. But cf. Costello v. United States, 350 U.S. 359 (1956), where the Court indicated that an indictment based entirely on hearsay testimony would not be set aside.

10 Blackstone indicates the significance of the grand jury in the following passage: "But to find a bill, there must at least twelve of the jury agree: for so tender is the law of England of the lives of the subjects, that no man can be convicted at the suit of the king of any capital offense, unless by the unanimous voice of twenty-four of his equals and neighbors; that is, by twelve at least of the grand jury, in the first place, assenting to the accusation; and afterwards, by the whole petit jury, of twelve more, finding him guilty, upon his trial." 4 Blackstone, Commentaries -301. "But these informations (of every kind) are confined by the constitutional law to mere mis. demeanors only: for, wherever any capital offense is charged, the same law requires that the accusation be warranted by the oath of twelve men, before the party should 
Bill of Rights as a restraint upon governmental prerogative-accompanied by the guarantees against self-incrimination, double jeopardy and deprivation of due process-convincingly indicates the dominant character of the protective role. ${ }^{17}$

\section{Characteristics of the Proceeding}

Certain peculiar characteristics of the grand jury proceeding dictate, in part, the scope and the nature of the witness' rights. In the first instance, grand jury proceedings are ex parte ${ }^{18}$ and, absent special statutory provisions to the contrary, the accused has neither the right to appear as a witness ${ }^{19}$ nor to compel the body to hear his witnesses. $^{20}$ Yet, if the grand jury desires, it may compel persons, including the accused, to appear as witnesses under subpoena.21

be put to answer it." Id. at "305. See also 2 Hawkins, Pleas of the Crown 294 (8th ed. Curwood 1824) where the author observes that dispensing with the grand jury would be "contrary not only to the common law, but to MAGNA CHARTA, and other statutes made in affirmance of it."

${ }^{17}$ See Hurtado v. California, 110 U.S. 516, 545-58 (1884) (Harlan, J., dissenting). See also Wood v. Georgia, 370 U.S. 375, 390 (1962) (Warren, C. J.): "Historically, [the grand jury] ... has been regarded as a primary security to the innocent against hasty, malicious and oppressive persecution; it serves the invaluable function in our society of standing between the accuser and the accused ... to determine whether a charge is founded upon reason or was dictated by an intimidating power or by malice and personal ill will." But see In re Grand Jury Proceedings, 4 F. Supp. 283, 284 (E.D. $\mathrm{Pa}$. 1983): "The inquisitorial power of the grand jury is the most valuable function which it possesses to-day and, far more than any supposed protection which it gives to the accused, justifies its survival as an institution." A particular court's view of the primary function of the grand jury might even affect the outcome of a case. Compare United States v. Cleary, 265 F.2d 459 (2d Cir.), cert. denied, 360 U.S. 936 (1959), with United States v. Cleary, 164 F. Supp. 328 (S.D.N.Y. 1958) (same case below).

${ }^{18}$ Hale v. Henkel, 201 U.S. 43, 65 (1906); State v. Stallings, 25 Conn. Supp. 386, 206 A.2d 277 (Super. Ct. 1964). "The investigation made by the grand jury is an $e x$ parte inquiry, in which only the evidence for the prosecution is heard." ORFIELD 162.

10 United States ex rel. McCann v. Thompson, 144 F.2d 604, 605 (2d Cir.), cert. denied, 323 U.S. 790 (1944). Exemplifying a modification of this rule, New York has provided that, "when any person has reason to believe that a grand jury is investigating a charge that he has committed a crime" he may petition for an appearance which may be granted in the grand jury's discretion if the person signs a waiver of immunity. N.Y. CODE CRIM. Proc. \$250. See also OkLA. Stat. ANN. tit. 22, §335 (Supp. 1964).

${ }_{20}$ Respublica v. Shaffer, 1 Dall. 236 (Pa. 1788). Under special circumstances, the normal functioning of a grand jury may be altered by statute with the result that additional protections are extended to the accused. Thus, in Georgia, it is provided by statute that one accused of malfeasance in office shall have the right to stage a preliminary defense before the grand jury with the derivative rights to the assistance of counsel and to call witnesses. GA. CoDE ANN. $\$ 40-1617$ (1935). See Clinkscales v. State, 102 Ga. App. 670, 117 S.E.2d 229 (1960); Cadle v. State, 101 Ga. App. 175, 113 S.E.2d 180 (1960).

${ }^{a x}$ See text accompanying notes $31-32$ infra. Statutes often direct, or at least make provision for, the grand jury to hear evidence for an accused where such information 
Furthermore, the grand jury has great latitude with respect to the matters it may probe. ${ }^{22}$ So long as the body does not infringe upon a witness' rights or privileges, it is not restricted in its receipt of evidence or course of inquiry by the rules which govern a criminal trial. 23

would tend to exculpate him. E.g., CAL. PEN. CODE \$ 939.7; IOwa CODE \$771.15 (1962); LA. Rev. Stat. \$15:214 (1950); Mont. Rev. Codes ANN. \$94.6319 (1947). But see CoLo. Rev. Stat. ANN. 39-3-2 (1963) (grand jury shall hear only witnesses for the state). 23 "It is a grand inquest, a body with powers of investigation and inquisition, the scope of whose inquiries is not to be limited narrowly by questions of propriety or forecasts of the probable result of the investigation, or by doubts whether any par. ticular individual will be found properly subject to an accusation of crime." In re Black, $47 \mathrm{~F} 2 \mathrm{~d}$ 542, 544 (2d Cir. 1931). "The sources of grand jury information are almost unlimited." United States v. Smyth, 104 F. Supp. 288, 296 (N.D. Cal. 1952). See also Blair v. United States, 250 U.S. 273 (1918). See generally Orfield, supra note 2 , at $394-402$.

The scope of state grand jury proceedings is often limited by the common juris. dictional limitation that it shall investigate only alleged offenses triable within the county where it is sitting. E.g., CAI. PEN. Code $\$ 917$; FLA. STAT. ANN. $\$ 905.16$ (1944); IDAHO CODE ANN. §19-I10I (1947); IND. ANN. STAT. \$9-807 (1956). Another possible limitation on the jurisdictional power may exist when a so-called special grand jury is convened to investigate a particular matter. See S.D. Code \$34.1203 (Supp. 1960).

${ }^{23}$ Most of the matters protected from consideration by the grand jury are those which a particular witness will be privileged from disclosing. The operation and scope of these privileges will be separately considered later (see notes 99-107 infra and ac. companying text); however, the proper scope of the grand jury investigation can be important not only where the witness challenges a particular line of inquiry but also where a defendant challenges the basis of a true bill. Where the challenge is to the evidence constituting the basis of the accusation the courts have been quite reluctant to circumscribe the grand jury's investigational scope by overturning indictments. The reasons for this reluctance to supervise the body more closely include the follow. ing:

(1) The grand jury proceeding is not an adversary action, and, although important (see note 17 supra and accompanying text), it does not finally adjudicate rights or obligations;

(2) The judge does not preside over the proceeding to minimize exrors in their incipiency; and

(3) Undue time and effort would be consumed by making the grand jury the situs of a preliminary trial to determine whether there should be a full-fledged trial. Costello v. United States, 350 U.S. 359, 363 (1956).

Thus, in Costello v. United States, supra, the Court held that an indictment based entirely on hearsay evidence would not be set aside. See note 15 supra and accompany. ing text. See also Lawn v. United States, 355 U.S. 389, 349-50 (1958) (no right to a separate lrearing to determine whether illegal evidence was used); United States v. Block, 202 F. Supp. 705 (S.D.N.Y. 1962) (refusal to set aside indictment where grand jury heard illegally seized evidence on grounds that it might not have been the only evidence). But see Jones v. United States, 342 F.2d 863 (D.C. Cir. 1964) (requiring that an indictment be supported by some other evidence than an unconstitutionally obtained confession). See generally Silverstein, Federal Grand Jury Testimony and the Fifth Amendment, 1960 WASH. U.L.Q. 215; Note, 111 U. PA. L. REv. 1154 (1963); Note, 72 YALE L.J. 590 (1963).

State statutory modifications in various forms would appear to alter the general rule that the grand jury may hear incompetent evidence. The most restrictive type 
The most important feature of grand jury procedure as far as a witness is concerned is the fact that the institution operates in camera. $^{24}$ Neither the judge of the court under which it is convened nor the counsel of the witness may be present during the proceedings. ${ }^{25}$ Generally, the only persons who are permitted in the grand jury room are the grand jurors, the witness, a stenographer, and the prosecuting attorney who directs the course of the investigation and acts as a legal advisor to the grand jury. ${ }^{26}$ To preserve the

of statute is exemplified by S.D. Cone $\$ 34.1224$ (Supp. 1960): "The grand jury can receive none but legal evidence and the best evidence in degree, to the exclusion of hearsay or secondary evidence." Accord, CAL. PEN. CODE §939.6; Idaho Code ANN. \$19-1105 (1947); MinN. Stat. ANN. \$628.59 (1945); Mont. Rev. Codes ANN. 94-6318 (1947); Nev. Rev. Stat. \$172.260 (1963); N.Y. Code Crim. Proc. \$§ 249-50; N.D. CENT. CODE $\$ \S 29-10-23$ to -24 (1960); ORE. REv. STAT. $\$ 132.320$ (1963). Other statutes would apparently exclude some, but not all, incompetent evidence. E.g., ALA. Code tit. 30, $\S 86$ (1958); ARK. STAT. ANN. \$43.918 (1947); IOWA CODE $§ 771.17$ (1962); LA. REv. Stat. § 15:213 (1950); OkLA. Stat. ANN. tit. 22, § 333 (Supp. 1964). See generally Note, 1963 WASH. U.L.Q. 102, 111-15.

24 The "indispensable secrecy of grand jury proceedings" is often acclaimed by the courts. United States v. Proctor \& Gamble Co., 356 U.S. 677, 682 (1958); Pittsburgh Plate Glass Co. v. United States, 360 U.S: 395 , 399-400 (1959). The purposes of grand jury secrecy were summarized in United States v. Rose, 215 F.2d 617, 628-29 (3d Cir. 1954) as follows: "(1) To prevent the escape of those whose indictment inay be contemplated; (2) to insure the utmost freedom to the grand jury in its deliberations, and to prevent persons subject to indictment or their friends from importuning the grand jurors; (3) to prevent subornation of perjury or tampering with the witnesses who may testify before [the] grand jury and later appear at the trial of those indicted by it; (4) to encourage free and untrammeled disclosures by persons who have information with respect to the commission of crimes; (5) to protect [an] innocent accused who is exonerated from disclosure of the fact that he has been under investigation, and from the expense of standing trial where there was no probability of guilt." An additional purpose for grand jury secrecy which was candidly admitted in United States v. Smyth, 104 F. Supp. 283, 289 (N.D. Cal. 1952), is to aid the prosecutors and permit them to influence the grand jury.

While the bulk of the cases dealing with grand jury secrecy arise where there is an attempt to discover the contents of the proceedings for purposes related to use thereof at a subsequent trial, see Dennis v. United States, 384 U.S. 855 (1966), the tenacity of the secrecy requirement may directly affect the latitude of the rights afforded to a witness. See note 120 infra and accompanying text.

${ }^{25}$ See text accompanying notes $108-18$ infra. It may be possible for the judge to appear briefly for the purpose of giving advice or elaborating upon his charge, but thereafter the grand jury generally performs its investigative function without the judge's presence. See e.g., ARK. Stat. ANN. \$43.932- (1947); CAL. Pen. Code § 935; MONT. REv. CODEs ANN. \$94-6324 (1947). The judge's assumption of control over the grand jury is thereby prevented. See O'Bryan v. Chandler, 249 F. Supp. 51, 55 (WD. Okla. 1964), aff'd, 352 F.2d 987 (10th Cir. 1965).

${ }^{20}$ See, e.g., Fed. R. Crim. P. 6; Ariz. R. CrIm. P. 98; Ill. Rev. Stat. ch. 38, \$ 112-6 (Supp. 1965). See also United States v. Edgerton, 80 Fed. 374, 375 (D. Mont. 1897), where an indictment was quashed because an expert witness was allowed to remain in the grand jury room during the testimony of another witness.

However, North Carolina does not allow the prosecuting attorney to be present in the grand jury room. See Lewis v. Commissioners, 74 N.C. 169, 173 (1876). Some 
secrecy of the inquisition the grand jurors take an oath not to disclose any details concerning the proceedings. ${ }^{2 \pi}$

\section{The Witness' Pre-Testification Rights: Limitations on the Subpoena Power}

\section{A. Subpoena ad testificatum}

The witness' initial encounter with the grand jury usually involves the receipt of a subpoena ad testificatum. Unless the subpoena itself is invalid for failure to comply with the statutory prerequisites, ${ }^{28}$ the recipient must respond by appearing pursuant to the order of the court issuing it. ${ }^{29}$ Failing to do so without good

states, in lieu of or in addition to a stenographer, also provide that one of the grand jurors be appointed "clerk" with the responsibility of transcribing minutes of the proceedings. E.g., Ariz. R. Crum. P. 94; ARK. Stat. ANN. \$ 43-905 (1947).

${ }^{22}$ A typical oath for the grand jurors is found in OHro REv. CODE ANN. $\$ 2939.06$ (Page 1953): "You and each of you do solemnly swear that you will diligently inquire, and true presentment make of all such matters and things as shall be given you in charge or otherwise come to your knowledge ....; the counsel of the state, your own, and your fellows, you shall keep secret unless called on in a court of justice to make disclosures ...." Accord, Ind. ANn. Stat. \$9.807 (1956); ME. Rev. Stat. ANN. ch. $208, \S 1252$ (1964).

There are, in reality, three separate aspects to the secrecy requirement which shrouds the grand jury. The first is to keep secret the identity of the person being investigated until that person is in the custody of the police or free on recognizance. E.g., ALA. CODE tit. 30, §95 (1958); IOWA CODE $\$ 771.23$ (1962). The second aspect involves the generally absolute command that the grand jurors may not disclose the content of grand jury deliberations or votes to which only the jurors themselves were privy. E.g., ARIz. R. CRIM. P. 106; GA. Code ANN. §59-303 (1965); IDAmo CODE ANN. §19-1119 (1947). The final element of the secrecy oath imposes a qualified silence on the jurors not to divulge the testimony of witnesses who appeared before them. E.g., Aruz. R Crum. P. 107; CAl. Pen. COde § 924.2; Idaho Code ANN. § 19-1112 (1947).

A violation of this oath by a grand juror may result in a conviction for contemp1 of court, see, e.g., In re Atwell, 140 Fed. 368 (W.D.N.C. 1905), or other statutor) penalty, see, e.g., ARK. Stat. ANN. § 43-929 (1964); CAL. PeN. CODE §924.1. While it hat been held that the courts also have an inherent discretionary power to impose the secrecy requirement on grand jury witnesses, Goodman v. United States, 108 F.2d 51 ( (9th Cir. 1939), statutes in some jurisdictions have pre-empted the area and deniec such power. See Advisory Committee's Note, 18 U.S.C. App. at 140 (1964); DEL. SUPER Cr. (Crim.) R. 6. But see Fla. Stat. AnN. \$905.27 (Supp. 1965); Hawait Rev. Law. $\$ 279-1$ (1955); TEx. Code Crum. Proc. art. 388 (1954). It is common to require secrec: from stenographers and any necessary interpreters. E.g., MD. ANN. CODE art. 26, §4: (1957); Mo. Rev. Stat. \$540.105 (1949); Uniform Rule of Cruminal Procedure 11 (1952).

${ }^{28}$ See generally 8 WIGMORE, EVIDENCE $\$ \$ 2199-2200$ (1961 ed.) [hereinafter cited a WrGMORE], where the author canvasses the necessary elements of a valid subpoena.

${ }^{20}$ See 8 Wigmore $\$ \S 2204-07$, where the circumstances under which an excusabl inability to attend in response to a subpoena are delineated.

While the court must generally issue subpoenas, some states allow other officials tt issue them at the request of the grand jury. See, e.g., ALA. CODE tit. 30, $\$ 83$ (1958) N.Y. Code Crim. Proc. §609; Tex. Code Crim. Proc. art. 382 (1954). 
cause may constitute contempt of court. ${ }^{30}$ Generally the recipient is not privileged to refuse to respond merely because he is the object of the investigation; ${ }^{31}$ however, in some jurisdictions, either by rule

${ }^{80}$ See, e.g., AlA. CODE tit. $30, \$ 47$ (1958); TEX. CODE CRIM. Proc. art. 474 (1954).
91 Persons who deem themselves the object of a grand jury investigation have often
claimed the right not to appear or have challenged an indictment on the grounds that
they were called as a witness, asserting, in either case, that the privilege against self-
incrimination prohibited such compulsory appearance by analogy to a criminal trial.
The federal courts have generally refused to sustain such objections but have indicated
that there may be limits with respect to who may be called and under what circum-
stances the inquiry may proceed. In the early case of United States v. Edgerton, 80
Fed. 374 (D. Mont. 1897), the court, quashing indictments as procured in violation of
the privilege against self-incrimination, stated: "It is fatal to the indictments that the
defendant was called to testify in the particular matter from which they resulted,
without being informed or knowing that his own conduct was the subject under inwithout being informed or knowing that his
vestigation." Id. at 375 . (Emphasis added.)

The Edgerton requirement that the witness be informed that his own conduct is being scrutinized was not alluded to in United States v. Blanton, 77 F. Supp. 812 (E.D. Mo. 1948), where the court found no error in indictments returned against a witness and allegedly supported by his own testimony; however, the court commented that "such practice is not to be commended [because] ... prosecuting officials should be careful to protect the constitutional rights of all citizens." Id. at 816.

In United States v. Lawn, 115 F. Supp. 674 (S.D.N.Y.-1953), the court set aside an indictment on constitutional grounds where the defendants testified before the grand jury giving evidence which "furnished a link in the chain of evidence needed to convict them for the crimes charged." Id. at 678. It did so, however, by confining itself largely to the particular facts: "An indictment is invalid if a defendant against whom a criminal information has been filed, is called by the prosecution as a witness before the grand jury to obtain evidence tending to sustain an indictment against him which supersedes the earlier information." Id. at 677. (Emphasis added.) Thus, the two necessary elements for invalidity were (1) the pendency of a formal accusation and (2) the attempt of the prosecutor to obtain incriminating information. See Note, 45 IOWA L. REv. 564 (1960).

In United States v. Manno, 118 F. Supp. 511 (N.D. IIl. 1954), the court rejected defendant's motions to dismiss various indictments in language broadly restrictive of the scope of the self-incrimination privilege. Defendant had argued that summoning a prospective defendant constitutionally prohibited a subsequent indictment, while the Government denied that the defendant was a prospective defendant when he was called; however, the decision did not find such a distinction to be determinative. Thus, the court concluded that "the protection afforded by the Fifth Amendment is to permit a person to claim the privilege against self-incrimination if he wishes so to do but the Amendment does not prevent his being called to testify where he makes his election to testify or not to testify." Id. at 517. See United States v. Irwin, 354 F.2d 192, 199 (2d Cir. 1965), cert. denied, 383 U.S. 967. (1966); United States v. Winter, 348 F.2d 204, 207 (2d Cir.) (reviewing authorities), cert. denied, 382 U.S. 955 (1965); United States v. Parker, 244 F.2d 943 (7th Cir.), cert. denied, 355 U.S, 836 (1957); United States v. Gilboy, 160 F. Supp. 442, 461 (M.D. Pa. 1958); In re Grand Jury Proceedings, 4 F. Supp. 283 (E.D. Pa. 1933). See also United States v. Rosen, 353 F.2d 523 (2d Cir. 1965), cert. denied, 383 U.S. 908 (1966); Carlson v. United States, 209 F.2d 209 (lst Cir. 1954). The broad language of the Manno case expresses what appears to be the majority rule in the federal courts.

In United States v. Scully, 225 F.2d 113 (2d Cir.), cert. denied, 350 U.S. 897 (1955), the court refused to disturb a conviction by vacating indictments returned subsequent to defendant's appearance before the grand jury. Error was urged in the grand jury's 
or practice, the grand jury is not permitted to subpoena those who are actually being investigated. ${ }^{32}$

failure to warn the allegedly prospective defendant of his right not to incriminate himself. The court held that "until a formal charge is openly made against the accused" no such warning was necessary. 225 F.2d at 114-15. To like effect, see United States v. Klein, 247 F.2d 908, 920 (2d Cir. 1957), cert. denied, 355 U.S. 924 (1958). See note 61 infra and accompanying text.

In United States v. Grossman, I54 F. Supp. 813 (D.N.J. 1957), the court, after an extensive review of the authorities, rejected defendant's claim that a person marked for prosecution could not be called by a grand jury investigating him. The court adhered to the general rule "apparently firmly established by all the recent Federal decisions ... that, even if the defendants were so marked, calling them before the Grand Jury is not grounds for the quashing of the Indictment provided (1) no complaint or indictment is then actually outstanding against them and (2) they are not compelled to testify." Id. at 816 .

The failure to wam a withess who was the object of the grand jury investigation was considered to be the crucial fact in United States v. DiGrazia, 213 F. Supp. 232 (N.D. Ill. 1963), where indictments returned subsequent to the testimony were set aside. The court rejected the view tbat any labeling of the witness as "witness, possible defendant, prospective defendant, putative defendant, named defendant" would be determinative. Therefore, the test laid down by the court was much broader than the rule in United States v. Scully, supra, and may be summarized as follows: "[N]o individual who is not warned of his privilege against self-incrimination and executes a formal immunity waiver either upon advice of counsel or after declining such advice, may subsequently be indicted for an offense about which he was questioned before the Grand Jury." 213 F. Supp. at 234. But see note 65 infra and accompanying text.

The waters have been further muddied by the recent case of Jones v. United States, 342 F.2d 863 (D.C. Cir. 1964), where the court, in the exercise of its supervisory power over the administration of justice, held that the prospective defendant should not be taken before the grand jury without prior advice of counsel. However, five concurring judges felt there was a serious question as to whether the Constitution permitted the bringing of a "person against whom an indictment is being sought" before the grand jury. Id. at 867 .

While it is clear from a review of the cases that the outermost limits to which a federal grand jury may go in calling prospective defendants have not been definitively established, it is likewise evident that no blanket immunity from non-appearance exists for the witness whose own conduct is or becomes the subject of the inquisition. Several states also follow the federal practice of allowing the appearance of prospective defendants: Sec, e.g., Burke v. State, 104 Ohio St. 220, 135 N.E. 644 (1922); Gendron v. Buruham, 146 Me. 387, 82 A.2d 773 (1951) (where the practice is criticized but not fatal to the indictments); TEx. CoDE CRIM. Proc. art. 389 (1954) (expressly recognizing the grand jury's authority to question the accused).

\$2 For example, New York has consistently held that, in keeping with the privilege against self-incrimination, "a person against whom the inquiry of the grand jury is directed should not be required to attend before that body, much less be sworu by it, and if he is and an indictment be found, it should be set aside upon motion and, if not, if the fact appears upon the trial, it will invalidate a conviction if one be had." People v. Gillette, 126 App. Div. 665, 670, 111 N.Y. Supp. 133, 136 (1908) (conviction for perjury before grand jury reversed because oath invalid). See People v. DeFeo; 308 N.Y. 595, 127 N.E.2d 592 (1955) (reversing contempt conviction for failure of prospective defendant to answer questions); People v. Werkes, 46 Misc. 2d 1020, 261 N.Y.S.2d 726 (Sup. Ct. 1965) (setting aside indictment where defendant was called); People v. Seaman, 174 Misc. 792, 21 N.Y.S.2d 917 (Sup. Ct. 1940); People v. Bermel, 71 Misc. 356, 128 N.Y. Supp. 524 (Sup. Ct. 1911). Other states have reached the same conclusion 


\section{B. Subpoena duces tecum}

The subpoena duces tecum is a device frequently employed by the grand jury to secure the production of books, records, or chattels for inspection. ${ }^{33}$ The form and method of service of the subpoena are prescribed by statute, compliance with which is essential to its validity. ${ }^{34}$ Furthermore, in order to command acquiescence, the subpoena must specify with "reasonable particularity" the objects sought to be produced. ${ }^{35}$ Besides specificity of designation, the scope of the subpoena is substantively limited by the constitutional mandate that the order for production must be "reasonable." 36 Reasonableness is determined by considering the grand jury's proper and potential use for the matter on the one hand and the witness' burdens of production on the other. ${ }^{37}$ Thus, where production would involve

as DeFeo and Werkes concerning the scope of the privilege against self-incrimination as it relates to the appearance of grand jury witnesses. E.g., People v. Calhoun, 50 Cal. 2d 137, 323 P.2d 427 (1958); State v. Jemison, 240 La. 787, 790-91, 125 So. 2d 363, 364 (1960). A person under investigation may appear in some circumstances at his own request. See note 19 supra and accompanying text.

33 See 4 Barron \& Holtzoff, Federal Practice \& Procedure \$2044 (Wright ed. 1961); 5 Moore, Federal Practice $\$ 45.05$ (2d ed. 1964); 8 Wigmore $\$ 2200$.

si See authority cited note 28 supra.

${ }^{35}$ See, e.g., Hale v. Henkel, 201 U.S. 43, 77 (1906); In re Eastman Kodak Co., 7 F.R.D. 760 (W.D.N.Y. 1947); United States v. Medical Soc., 26 F. Supp. 55 (D.D.C. 1938).

se The requirement that the subpoena must be "reasonable" is grounded in the fourth amendment. Hale v. Henkel, supra note 35, at 76; Schwimmer v. United States, 232 F.2d 855, 860 (8th Cir.), cert. denied, 352 U.S. 833 (1956); In re Grand Jury Investigation, I74 F. Supp. 393, 395 (S.D.N.Y. 1959); Southern Pac. Co. v. Superior Court, 15 Cal. 2d 206, 100 P.2d 302 (1940); Red Star Labs. Co. v. Pabst, 359 IIl. 451, 194 N.E. 734 (1935). This reasonableness criterion is also occasionally written into the statute authorizing the use of the subpoena, E.g., Fed. R. CRim. P. I7 (c); Mo. ANN. Stat. $\S 491.100$ (1949).

In the light of Mapp v. Ohio, 367 U.S. 643 (1961) (incorporating the privilege against illegal searches and seizures into the fourteenth amendment), this requirement of "reasonableness" would now appear to be universally mandatory.

a7 Hale v. Henkel, supra note 35, at 77, where the Court gave as one of its reasons for vacating the subpoena the fact that the burdens of compliance would threaten the witness' ability to carry on his business. See In re Grand Jury Investigation, 33 F. Supp. 367, 372 (M.D.N.C. 1940); United States v. Medical Soc., 26 F. Supp. 55 (D.D.C. 1938). However, the size of the corporate recipient of the subpoena is a significant factor in determining the weight of the burdens involved in compliance. Application of Radio Corp. of America, 13 F.R.D. 167, 172 (S.D.N.Y. 1952).

In Schwimmer v. United States, 232 F.2d 855 (8th Cir.), cert. denied, 352 U.S. 833 (1956), the court indicated the type of balancing involved in deciding the fourth amendment question as follows: "In general terms, the test to be applied under [the amendment] ... is whether the thing done or attempted to be done, in the sum of its form, scope, nature, incidents and effect, impresses as being fundamentally unfair or unreasonable in the specific situation, when the immediate end sought is considered against the private right affected." 232 F.2d at 861 . 
great expenditures of time, effort, or money and the grand jury's need for the materials is negligible, the subpoena may be avoided. ${ }^{38}$ However, where it appears that production might advance the investigation and the only objection is based upon inconvenience to the witness, the courts generally defer to the grand jury's request. ${ }^{30}$ Furthermore, the reasonableness of the subpoena is not conclusively determined by the possible inadmissibility of the material at a subsequent trial. ${ }^{40}$

Non-compliance with the instructions of the subpoena duces tecum may also be justified where the grand jury is attempting to recover articles which have been previously taken or discovered by an illegal search and seizure and subsequently returned. Such materials might properly be excluded from governmental consideration in any circumstance as "fruits of the poisonous tree." 41

\footnotetext{
${ }^{88}$ There are numerous instances of situations where subpoenas have been quashed because the documents requested were too numerous or covered too great a span of time. Hale v. Henkel, supra note 35, at 77; Schwimmer v. United States, 232 F.2d 855, 862-63 (8th Cir.), cert. denied, 352 U.S. 933 (1956); In re Grand Jury Investigation, 174 F. Supp. 393 (S.D.N.Y. 1959); In re United Shoe Mach. Corp., 6 F.R.D. 347 (D. Mass. 1947); United States v. Medical Soc, supra note 37.

The courts may conclude that the need for the documents is slight where it appears that the grand jury is embarked upon an "unlimited exploratory investigation ... . whose purposes and limits can be determined only as it proceeds ...." In re Grand Jury Investigation, supra at 395 . Thus, to a limited degree, the subpoenas of a runaway grand jury, off on a "fishing expedition," may be somewhat more vulnerable to an attack upon "reasonableness" grounds than those of juries whose mandate is more circumscribed. See Schwimmer v. United States, supra note 37.

Although the separate factors which will make a subpoena duces tecum unreasonable can be identified from the cases, the courts have not established definitive rules to assist in the quest for determining reasonableness. The decisions proceed on an ad hoc basis rendering precedent of "little value." Application of Radio Corp. of America, supra note 37 , at 171 .

${ }^{30}$ Only in "rare cases ... should [the court] exercise its power to deny process to the Grand Jury." Id. at 172. See In re Grand Jury Investigation, 32 F.R.D. 175 (S.D.N.Y. 1963); Petition of Borden Co., 75 F. Supp. 857 (N.D. Ill. 1948).

"Subpoenas are often attacked on the grounds that the material sougbt is "irrele. vant." Although this objection may be a factor in determining "reasonableness," nevertheless to the extent that a finding for the recipient would circumscribe the grand jury's inquisitorial power, the courts are reluctant to quash the subpoena. See Hale v. Henkel, 201 U.S. 43 (1906); Application of Radio Corp. of America, 13 F.R.D. 167 (S.D.N.Y. 1952). But cf. Red Star Labs. Co. v. Pabst, 359 Ill. 45l, 194 N.E. 734 (1935); CAL. Crv. Proc. Code $\$ 1985$.

"The leading case involving the use of illegally seized material is United States $v$. Silverthorne, 265 Fed. 859 (W.D.N.Y. 1920), where the court quashed an indictment which was obtained on the basis of evidence secured in an illegal search and seizure. See Note, I11 U. PA. L. REv. 1154, 1167-72 (1963). The Silverthorne litigation eventually reached the Supreme Court on a fresh indictment and there the Court set down the "fruits of the poisonous tree" doctrine which requires exclusion not only of evidence obtained during an illegal search and seizure, but also of evidence suggested
} 
A related limitation on the subpoena duces tecum is the witness' absolute privilege against surrendering under compulsion documents which would be self-incriminatory. ${ }^{42}$ While questions as to the scope and manner of determining the privilege are the same as for testification, ${ }^{43}$ unique problems arise where the information sought has been reduced to tangible form. The difficulty stems from the nature of the privilege, which is personal to the "holder" of the information and thus cannot be claimed for another's benefit. ${ }^{44}$ For example, a mere custodian of corporate or union papers cannot refuse to produce such documents by invoking the self-incrimination privilege.45 Two limitations on the custodian rule, however, may be indicative of a reluctance by the courts to narrowly circumscribe the scope of the privilege. It has been held that while a custodian cannot refuse to produce documents in his possession, he may refuse to testify

by and unearthed in consequence of such illegal search. Silverthorne Lumber Co. v. United States, 251 U.S. 385 (1920). In In re Fried, 161 F.2d 453 (2d Cir.), cert. denied, 331 U.S. 858 (1947), the court also acted to prevent the grand jury from considering constitutionally "illegal" evidence in the form of a coerced confession. The decision in In re Fried, however, was based upon a view of the grand jury which has not attained widespread acceptance. Judge Frank emphasized the adverse effects of a true bill on the accused as a reason for demanding stringent control over the evidence the grand jury is allowed to consider: "For a wrongful indictment is no laughing matter; often it works a grievous, irreparable injury to the person indicted. The stigma cannot be easily erased. In the public mind, the blot on a man's escutcheon, resulting from such a public accusation of wrongdoing, is seldom wiped out by a subsequent judgment of not guilty. Frequently the public remembers the accusation, and still suspects guilt, even after acquittal." $16 \mathrm{I}$ F.2d at 458-59. But cf. Costello v. United States, 350 U.S. 359 (1956).

FED. R. CRIM. P. 41 (e) permits a person "aggrieved by an unlawful search and seizure" to recover the property and suppress its use as evidence before trial. However, the extent to which the states are constitutionally required by the fourteenth amendment to suppress the use of illegal evidence in the preliminary stages of a prosecution, includiug the grand jury proceeding, is not yet certain.

12 The application of the testimonial privilege against self-incrimination to the protection of communicative documents is constitutionally guaranteed by joint operation of the fourth and fifth amendments-compelled production of incriminating documents being per se unreasonable. Malloy v. Hogan, 378 U.S. I (1964).

Similarly, where a person has given a privileged document to his lawyer in the course of an attorney-client relationship, the lawyer cannot be compelled to produce it by reason of the combined effect of the attorney-client and self-incrimination privileges. United States v. Judson, 322 F.2d 460 (9th Cir. 1963). See 8 WigmorE $\S 2307$.

's See text accompanying notes $68,74-78,80-85$ infra.

"See 8 Wigmore $\$ 2270$. But see note 41 supra.

"S Curcio v. United States, 354 U.S. 118, 122 (1957) (dictum); United States v. White, 322 U.S. 964 (1944) (labor official may not claim privilege for union books to protect himself); Wilson v. United States, 221 U.S. 361 (1911) (agent of corporation cannot refuse to produce corporate records to protect himself); Hale v. Henkel, 201 U.S. 43 (1906) (agent of corporation cannot assert privilege to protect corporation). 
about them or to reveal their whereabouts if by so doing he would incriminate himself. ${ }^{46}$ Furthermore, a partner in possession of partnership papers may claim the privilege at least where the partnership is of the small family type. ${ }^{47}$

In addition to the protections afforded by the complementary operation of the privilege against self-incrimination and the right against unreasonable searches and seizures, the recipient of the subpoena is also protected from disclosing or having disclosed against him material which is shielded from governmental consideration by an applicable statutory privilege. The scope of these privileges is the same as for testification and the problems of their operation are discussed later. ${ }^{48}$

Where the recipient wishes to challenge the subpoena duces tecum for any of the aforementioned reasons, the appropriate method is a motion to quash directed to the court which originally issued the process. ${ }^{49}$ In the federal courts, denial of the motion to quash the subpoena is not a "final order" and hence is not appealable, "50 but a wrongful refusal to produce the subpoenaed material may create the danger of a contempt conviction from which an appeal will lie.51 However, since the witness who receives a subpoena duces tecum will ordinarily have time to consult counsel, thereby minimizing the likelihood of a wrongful refusal to comply, his position is less pre-

${ }^{18}$ Curcio v. United States, 345 U.S. 118 (1957). See also United States v. Guterma, 272 F.2d 344 (2d Cir. 1959), where the court invalidated a subpoena insofar as it would have compelled appellant to reveal a safe combination and thereby make available certain corporate books incriminating himself.

${ }^{47}$ In re Subpoena Duces Tecum, 81 F. Supp. 418 (N.D. Cal. 1948).

${ }^{48}$ For a discussion of the various relevant common law and statutory privileges, see notes 102-07 infra and accompanying text.

${ }^{19}$ FED. R. CRIM. P. 17 (c). Under state procedure a variety of means may be available to attack the issuance of a subpoena. These include a writ of prohibition, see Southern Pac. Co. v. Superior Court, 15 Cal. 2d 206, 100 P.2d 302 (1940); and a motion to quash or vacate, see Pelton Motors, Inc. v. Superior Court, 120 Cal. App. 2d 565, 261 P.2d 275 (Dist. Ct. App. 1953).

In order to have the subpoena quashed, the recipient may be required to produce the requested documents so that the court may pass on asserted grounds for objections. Consolidated Rendering Co. v. Vermont, 207 U.S. 541 (1908); Schwimmer v. United States, 232 F.2d 855, 864 (8th Gir.), cert. denied, 352 U.S. 833 (1956).

${ }^{\text {so }}$ Cobbledick v. United States, 309 U.S. 323 (1940); Dugan \&: McNamara, Inc. v. Clark, 170 F.2d 118 (3d Cir. 1948); Orfield, supra note 2, at 388. But see Perlman v. United States, 247 U.S. 7 (1917); Schwimmer v. United States, 232 F.2d 855, 866 (8th Gir.), cert. denied, 352 U.S. 833 (1956). Review, of course, is permitted after a final judgment where the subpoena has required an illegal search and seizure and a lower court order is therefore tainted.

${ }^{51}$ E.g., Brown v. United States, 276 U.S. 134 (1928). See FED. R. CRIM. P. 17 (g). 
carious than that of the testifying witness who must fend entirely for himself during testification.

\section{Testification}

\section{A. Privilege against self-incrimination}

The privilege of the fifth amendment against compulsory selfincrimination has long been applied to federal grand jury proceedings, ${ }^{52}$ and its recent extension to state proceedings through the fourteenth amendment assures its universal applicability. ${ }^{53}$ In the light of the wide range of matters into which the grand jury may permissibly delve, ${ }^{54}$ the testimonial privilege against self-incrimination is clearly the bulwark right of the witness. The privilege is rendered doubly important in those jurisdictions in which certain future defendants may be compelled to appear as witnesses. ${ }^{65}$ Future defendants, to whom the proper exercise of the privilege is especially crucial, have been classified as de jure, 'de facto, or merely potential defendants. ${ }^{56}$ A de jure defendant is a witness who, at the time of his appearance, is already formally charged with the crime being investigated or against whom an indictment is pending; 57 whereas a

${ }^{62}$ Counselman v. Hitchcock, 142 U.S. 547 (1892). See Silverstein, supra note 23.

${ }^{83}$ Malloy v. Hogan, 378 U.S. 1, 3 (1964) (see note 7 supra), implicitly overruling Twining v. New Jersey, 211 U.S. 78 (1908). In Malloy, the Court purported to reject the "notion that the Fourteenth Amendment applies to the States only a "watereddown, subjective version of the individual guarantees of the Bill of Rights' . . ." 378 U.S. at 10-11. Sec also Murphy v. Waterfront Comm'n, 378 U.S. 52 (1964).

"See note 22 supra and accompanying text.

ss See notes 31.32 supra and accompanying text.

${ }^{50}$ Although some states have ruled that their constitutional privileges against self-incrimination prevent the calling of de jure or de facto defendants by the grand jury (see note 32 supra and accompanying text), the absence of a general rule to this effect as a matter of federal constitutional law (see note 31 supra and accompanying text) underscores the importance of proper invocation of the privilege during testification. See notes 60-64 infra and accompanying text.

The distinctions adopted here to differentiate among future defendants comport with certain holdings as to the relcvant factors on which compulsory appearance may or may not be had. As a practical matter, however, it is clear that the danger of selfincrimination may be equally significant to all of these witnesses since the only difference among their situations is the point in time at which they became the target of the inquiry. Sec Note, 45 Iowa L. REv. 564 (1960); Note, 67 YALE L.J. 1271 (1958). The particular terminology employed here is not widely adopted by the courts. Cf. United States v. DiGrazia, 213 F. Supp. 232, 233 (N.D. Ill. 1963). Nevertheless, the distinctions may be of some analytical assistance in discussing the grand jury witness.

${ }^{57}$ See, e.g., United States v. Cleary, 164 F. Supp. 328 (S.D.N.Y.), rev'd, 265 F.2d 459 (2d Cir. 1959); United States v. Lawn, 115 F. Supp. 674, 677 (S.D.N.Y. 1953) (indictments dismissed for calling de jure defendant to obtain incriminating evidence); State v. Clifford, 86 Iowa 550, 53 N.W. 299 (1892) (reversing conviction for failure to warn de 
de facto defendant is strongly suspected of being criminally involved in the activities under investigation but has not been formally charged. ${ }^{58}$ On the other hand, a potential defendant is a witness whose criminal activities are unknown to the grand jury but who is threatened with exposure during the course of the proceeding.50

Effective use of the privilege is essential, considering the extent to which testimony given before the grand jury may be used to the detriment of the witness. In addition to providing information for the formulation of an indictment, the testimony is available to the prosecution for building a case against the witness. ${ }^{00}$ Moreover, testimony voluntarily given before a grand jury may be admitted in a subsequent trial where the rules of evidence permit. ${ }^{81}$ Thus, such testimony has been introduced as an out-of-court admission to impeach trial testimony, to refresh memory, and to prove a criminal charge of perjury. ${ }^{02}$ However, the continued validity of the use of

jure defendant of privilege against self-incrimination). Compare United States v. Manno, 118 F. Supp. 511 (N.D. Ill. 1954), with United States V. Grossman, 154 F. Supp. 813 (D.N.J. 1957).

${ }^{8 B}$ See, e.g., United States v. Scully, 225 F.2d 113 (2d Cir.), cert. denied, 350 U.S. 897 (1955) (no need to advise witness of privilege where he was not formally charged with the crime under investigation); Burke v. State, 104 Ohio St. 220, 135 N.E. 641 (1922).

"D See, e.g., United States v. Manno, 118 F. Supp. 511, 517 (N.D. 11l. 1954), where the status of merely potential defendant was urged by the prosecution as a decisive factor. The court, however, felt that such a classification of the witness would not advance the inquiry.

oo "Disclosure of matters occurring before the grand jury other than its deliberations and the vote of any juror may be made to the attorneys for the government for use in the performance of their duties." FED. R. CRIM. P. 6(e). See also DEL. SuPER. CT. (CRrm.) R. 6 (e); INd. ANN. Stat. \$9-810 (Supp. 1966); Md. ANN. Code art. 26, § 39 (1957).

or Sec McCormick, Evidence $\$ 150$ (1954) [hereinafter cited as McCormick]; 8 WiGMORE § 2363; Annot., 5 A.L.R.2d 1404 (1949).

62 The admission at trial of the contents of a grand jury proceeding necessitates the circumvention of many obstacles. First, the grand jury testimony must fall within an exception to the hearsay rule: e.g., Grunewald v. United States, 353 U.S. 391, 41821 (1957) (dictum on impeachment); United States v. Socony-Vacuum Oil Co., 310 U.S. 150, 231-34 (1940) (refresh witness' memory); United States v. Collins, 272 F.2d 650 (2d Cir.), cert. denied, 362 U.S. 911 (1959) (operative fact in perjury prosecution); Metzler v. United States, 64 F.2d 203, 206 (9th Cir. 1933) (confession); United States v. Cotter, 60 F.2d 689, 692 (2d Cir.), cert. denied, 287 U.S. 666 (1982) (impeachment); United States v. Grunewald, 164 F. Supp. 640, 644 (S.D.N.Y. 1958) (admission); People v. Pickett, 339 Mich. 294, 63 N.W.2d 681, cert. denied, 349 U.S. 937 (1954) (admissible under statute requiring unavailability of declarant); State v. Broughton, 29 N.C. 96 (1846) (false accusation); Huidekoper v. Cotton, 3 Watts 56 (Pa. 1834) (operative fact for malicious prosecution).

Statutes often specify under what circumstances evidence given before a grand jury may be introduced as hearsay at trial. A common provision authorizes the use of a witness' testimony to impeach the witness or to prosecute him for perjury. E.g., ALA. Code tit. 30, §87 (1958); CAL. PEN. COde §924.2; MinN. Stat. ANN. §628.65 (1945); 
all grand jury testimony, procured under certain circumstances, may be questionable in the wake of Escobedo $v$. Illinois ${ }^{63}$ and Miranda v. Arizona. ${ }^{64}$

N.Y. Code Crim. Proc. § 259; Ore. Rev. Stat. \$132.220 (1959). Other statutes permit admission where justice will be promoted. E.g., ARIz. R. CRIM. P. 107; FLA. STAT. ANN. \$905.27 (Supp. 1965); IowA CODE §771.24 (1962). Some provisions merely require that the court order admissibility. E.g., DEL. SupER. CT. (CRIM.) R. 6 (e); GA. CODE ANN. \$59-302 (1965); IdAHo Code ANN. \$19-1112 (1947); ILI. Rev. STAT. ch. 38, §1126 (b) (Supp. 1965); Muss. Code ANN. \$1790 (1956).

Disclosure of the testimony heard by the grand jury may involve a violation of the secrecy oath; however, the veil of secrecy exists for the benefit of the grand jurors and the prosecution, and may be lifted where justice so requires. See United States v. Socony-Vacuum Oil Co., supra at 234; Huidekoper v. Cotton, supra at 57. It is the secrecy requirement, however, which prevents the defendant in the subsequent trial from wholesale access to the contents of the grand jury proceedings. See People v. Pickett, supra. Under the Federal Rules disclosure is permitted by order of the court. Frd. R. CrIM. Proc. 6(e). See Dennis v. United States, 384 U.S. 855, $871-72$ (1966).

As a final requisite to admissibility, the grand jury testimony must be free of the constitutional infirmities surrounding a coerced confession or incriminating information secured by infringement of the right to counsel. Reliance upon these grounds has been generally unsuccessful in attempts to exclude grand jury testimony from subsequent admission for at least two reasons: (1) Testification under oath is not coercion per se. In re Groban, 352 U.S. 330 (1957). But cf. State v. Clifford, 86 Iowa 550, 55153, 53 N.W. 299, 300 (1892). (2) Decisions establishing the expanded view of the right to counsel are of recent vintage and their impact upon grand jury proceedings is presently unclear. See notes 144-58 infra and accompanying text.

os 378 U.S. 478 (1964). "The Fifth Amendment and state constitutional provisions authorize, indeed require, inquisitorial grand jury proceedings at which a potential defendant, in the absence of counsel is shielded against no more than compulsory incrimination .... A grand jury witness, who may be a suspect, is interrogated and his answers, at least until today, are admissible in evidence at trial." Id. at 497-98 (White, J., dissenting). See United States v. Irwin, 354 F.2d 192, 199 (2d Cir. 1965), cert. denied, 384 U.S. 1011 (1966) (Escobedo inapplicable because witness "fully aware of this constitutional rights to remain silent and to consult with counsel"); People v. Sharer, 61 Cal. $2 d 869,877-78,395$ P.2d 899, 905 (1964). Cf. United States v. Winter, 348 F.2d 204, 206 (2d Cir.), cert. denied, 382 U.S. 955 (1965) (signed waiver); United States v. Grunewald, 164 F. Supp. 640, 641-42 (S.D.N.Y. 1958) (court recognized the possibility of a sixth amendment problem but found a waiver).

The effect of Escobedo and Miranda on the witness' rights is considered fully at notes 144-58 infra and accompanying text. However, assuming arguendo that the right to counsel accrues to the grand jury witness who has become the subject of the inquiry, the question arises as to whether all his testimony given after this point is inadmissible. Since the decision in Escobedo appears on its face to rest on the right to counsel and not on the coerced confession rule (see note 147 infra and accompanying text), it would appear to follow that no incriminating evidence procured by a deprivation of counsel could be used by the government for any purpose. Thus, whether the prosecutor attempted to use such information either to procure secondary evidence or to discredit the defendant at the trial (e.g., by impeachment), there would seemingly be a violation of constitutional rights. $C f$. United States v. Bolden, 355 F.2d 453, 458 (7th Cir. 1966).

of The fact that Miranda v. Arizona, 384 U.S. 436 (1966), underscored the fifth amendment self-incrimination basis of Escobedo might militate against the conciusion that all incriminating evidence short of a confession be excluded. However, the 
For the future defendant in particular, the privilege against selfincrimination may offer imperfect protection. Notwithstanding some authority to the contrary, ${ }^{65}$ the prevailing rule seems to be that the grand jury witness need not be warned of his privilege ${ }^{68}$ and must invoke it on his own initiative without the advice of counsel. ${ }^{67}$ Nor may the witness who apprehends danger rely upon a blanket refusal to answer any and all questions; ${ }^{88}$ rather, each claim of the privilege will succeed only where it can be shown that the particular answer would tend to subject the witness to criminal prosecution. ${ }^{30}$ Where the privilege has been relied upon but its assertion is challenged, the

Court held in Miranda that statements procured in contravention of the procedures set forth "whether exculpatory or inculpatory" are inadmissible. Id. at 476-77. "In fact, statements merely intended to be exculpatory by the defendant are often used to impeach his testimony at trial or to demonstrate untruths in the statement given under interrogation and thus to prove guilt by implication." Id. at 477 .

${ }^{05}$ In some states the failure to apprise a witness of his self-incrimination privilege has produced subsequent error. E.g., State v. Clifford, 86 Iowa 550, 53 N.W. 299 (1892) (confession before grand jury "involuntary" for failure to warn); State v. Jemison, 240 La. 787, 125 So. $2 d 363$ (1960); State v. Sibilia, 88 N.J. Super. 546, 212 A.2d 869 (Essex County Ct. 1965). See generally 8 Wigmore $\$ 2269$.

-o The rule that the witness-whether de jure, de facto, or potential defendant-need not be warned of his privilege appears to prevail in the federal courts. See United States v. Gilboy, 160 F. Supp. 442 (M.D. Pa. 1958); United States v. Manno, 118 F. Supp. 511 (N.D. Ill. 1954); United States v. Lawn, 115 F. Supp. 674 (S.D.N.X. 1953) (by implication). Several courts have indicated that it may be incumbent upon the grand jury to warn de jure defendants. United States v. Klein, 247 F.2d 908, 920 (2d Cir. I957) (dictum), cert. denied, 355 U.S. 924 (1958); Stanley v. United States, 245 F.2d 427, 434 (6th Cir. 1957) (dictum); United States v. Scully, 225 F.2d 113, 114-15 (2d Cir.) (dictum), cert. denied, 350 U.S. 897 (1955). For the view that a failure to warn a de jure, de facto, or potential defendant will invalidate indictments, see United States v. DiGrazia, 213 F. Supp. 232, 233-34 (N.D. Ill. I963).

Moved either by. a concern for the constitutional rights of the witness or by an attempt to avoid the rule of Escobedo (see note 147 infra), it is now common for the prosecutor to advise the witness of his right against self-incrimination. See, e.g., Kitchell v. United States, 354 F.2d 715, 720 (1st Cir. 1965), cert. denied, 384 U.S. I01I (1966); United States v. Irwin, 354 F.2d 192, 199 (2d Cir. I965), cert. denied, 383 U.S. 967 (1966); United States v. Winter, 348 F.2d 204, 207 (2d Cir.), cert. denied, 382 U.S. 955 (1965). Compare Miranda v. Arizona, 384 U.S. 436 (1966) (requiring a warning to one who is the target of a custodial interrogation).

o7 See United States v. Neff, 212 F.2d 297, 312 (3d Cir. 1954); text accompanying notes I08-18 infra.

${ }^{08}$ Enrichi v. United States, 212 F.2d 702 (10th Cir. 1954). In this respect, the dangers confronting the grand jury witness are far more acute than those facing the subject of a police interrogation where the right to absolute silence obtains and where the prospect of a perjury or contempt conviction is absent. But see Kitchell v. United States, 354 F.2d 715 (1st Cir. I965), cert. denied, 384 U.S. 1011 (1966), where the prose. cutor advised the witness that he did not have to say "anything." 354 F.2d at 720 n.9.

-o "It is not declared that he may not be compelled to testify to facts which may impair his reputation for probity, or even tend to disgrace him but the line is drawn at testimony that may expose him to prosecution." Hale v. Henkel, 201 U.S. 43, 66.67 (1906). 
question of the propriety of the reliance is referred to the judge of the court having jurisdiction over the grand jury. ${ }^{70}$ The witness has the burden of establishing, from all of the surrounding circumstances, that an answer to the question might subject him to criminal sanctions or provide a link in the chain of evidence leading to a criminal prosecution. ${ }^{71}$

If the judge determines that the claim of privilege is proper, the question may go unanswered. On the other hand, if the judge considers the claim to be groundless, he may order the witness to answer the question; and if the witness at this point persists in his refusal to testify, a contempt proceeding may be instituted. ${ }^{\mathbf{2}}$ Only after the witness has been found to be in contempt may he appeal the court order denying the propriety of his claim of the privilege. ${ }^{73}$

The witness should also be aware that he may inadvertently lose his right to claim the privilege by operation of the doctrine of waiver. ${ }^{44}$ Thus, the rule has been stated that "where criminating facts have been voluntarily revealed, the privilege cannot be invoked to avoid disclosure of the details." "75 There is considerable room for

${ }^{70}$ It is clear that the judge and not the witness must determine whether the privilege is properly invoked. Hoffman v. United States, 341 U.S. 479, 486-87 (1951); In re Hitson, 177 F. Supp. 834, 839 (N.D. Cal. 1959), rev'd on other grounds, 283 F.2d 355 (9th Cir. 1960). ARK. Stat. ANN. $\$ 43-916$ (1947); CAL. PEN. Code $§ 1324$; Iowa Code $\$ 771.10$ (1962). See generally 8 Wigmore $\$ 2271$; Annot., 38 A.L.R.2d 225 (1954).

71 See Hoffman v. United States, supra note 70, at 486.87; Blau v. United States, 340 U.S. 159, 161 (1950). The modern trend appears to be to allow the claim of the privilege upon a slight showing of actual danger of future prosecution. "To sustain the privilege, the witness need only make it evident from the question and its implications, considered in the setting in which it is asked, that the answer, or even an explanation as to why it cannot be answered might be dangerous, because an injurious disclosure might result." In re Hitson, 177 F. Supp. 834, 840 (N.D. Cal. 1959), rev'd on other grounds, 283 F.2d 355 (9th Cir. 1960). See, disapproving this trend, 8 WIGMORE $\$ 2260$. Liberal entertainment of a grand jury witness' claim of the privilege appears warranted when his circumstances are appreciated: "[T]he Fifth Amendment claim was made before a grand jury where Halperin was a compelled, and not a voluntary, witness; where he was not represented by counsel; where he could summon no witnesses; and where he had no opportunity to cross-examine witnesses testifying against him." Grunewald v. United States, 353 U.S. 391,422 (1957).

$7^{2}$ See, e.g., Rogers v. United States, 340 U.S. 367 (195I).

${ }^{73}$ This conclusion is implicit in Harris v. United States, 382 U.S. 162 (1965) (re. quiring a hearing before a contempt is found).

7 See generally McCormick $\$ 130 ; 8$ Wigmore $\$ \$ 2275-76$; Note, 61 YALE L.J. 105 (1952); Annot., 38 A.L.R.2d 225 (1954).

${ }^{75}$ Rogers v. United States, 340 U.S. 367, 373 (1951); accord, Brown v. Walker, 161 U.S. 591, 597 (1896); United States v. St. Pierre, 132 F.2d 837, 840 (2d Cir.), dismissed as moot, 319 U.S. 41 (1942). It would appear that if the custodial interrogation rules of Miranda were to be made applicable to the grand jury witness, the doctrine of waiver might no longer obtain. Miranda clearly permits the person interrogated to stop at any point. 384 U.S. at 474 . 
abuse in the application of this standard in the grand jury context since the witness is not entitled to the advice of counsel in framing his answers or selecting the questions that he will answer. ${ }^{76}$ Because of the "perverse effect" which the doctrine of waiver may have, ${ }^{77}$ a limited exception to its operation has been created where the "details" which the witness refuses to give constitute necessary elements in proof of the crime. ${ }^{88}$ Furthermore, the failure to claim the privilege while testifying before the grand jury does not waive the privilege with respect to the same inquiry in a subsequent trial..$^{70}$

The privilege may also be rendered inapplicable by a statutory grant of immunity to the recalcitrant witness. ${ }^{80}$ Immunity statutes are frequently employed in federal and state grand jury proceedings. Long recognized as a valuable means of procuring otherwise protected information, valid immunity provisions are bottomed on the principle that the privilege against self-incrimination applies only where the testimony could lead to criminal prosecution. ${ }^{81}$ Thus, in order for a grant of immunity to supplant fifth amendment protection, it must effectively insulate the witness from criminal prosecu-

${ }^{78}$ See, e.g., Rogers v. United States, 340 U.S. 367 (1951). The doctrine of waiver has reached climactic notoriety through its production of the predicamental situation so often faced by the much publicized witness before legislative investigating committees. Witnesses so situated, however, are allowed the advice of counsel in treading the fine line which separates a waiver by partial disclosure from contemptible refusal to answer non-incriminating questions. See Washington Post, Aug. 19, 1966, p. 1, where it is reported that Chairman Pool of the House Committee on Un-American Activities terminated a hearing after the witness' counsel had been forcibly ejected on the announced grounds that continued questioning might be in violation of the witness' rights.

778 WIGMORE $\$ 2276$.

78 United States v. Courtney, 236 F.2d 921 (2d Cir. 1956).

${ }^{70}$ E.g., In re Neff, 206 F.2d 149 (3d Cir. 1953); Ex parte Sales, 134 Cal. App. 54, 24 P.2d 916 (Dist. Ct. App. 1933); People v. Walker, 28 I11. 2d 585, 192 N.E.2d 819 (1963). See Annot., 36 A.L.R.2d I403 (1954).

so The immunity grants are statutory and vary in their operation. The statute may extend immunity automatically to one who is called to testify as provided, for example, in the Sherman Act $\S 1$, 32 Stat. 904 (1903), 15 U.S.C. $\$ 32$ (1964), which is explicated in United States v. Monia, 317 U.S. 424 (1943). See ALA. CoDE tit. 28, $\S 90(13)$ (1958); ALA. CODE tit. 29, $\S \S 171,234$ (1958). Immunity from prosecution may be provided only after the witness has claimed the privilege against self-incrimination. E.g., Securities Exchange Act $\$ 22,48$ Stat. 86 (1939), 15 U.S.C. $\$ 77 v$ (c) (1964); Micr. STAT. ANN. \$28.946 (1954). The statute also may empower the grand jury to confer immunity from prosecution, e.g., N.Y. PEN. CODE $\$ 2447$ (3) (c), or leave this discretion to the court, e.g., ILL. REv. STAT. ch. 38, \$106.1 (1964). Absent a statutory provision to the contrary, the mere calling of a witness by the grand jury does not confer immunity from prosecution with regard to the subject matter of the testimony. United States v. Smyth, 104 F. Supp. 283, 307 (N.D. Cal. 1952).

${ }^{81}$ See Brown v. Walker, 161 U.S. 591, 594 (1896). 
tion for any acts disclosed by his testimony. ${ }^{82}$ The Supreme Court in Counselman $v$. Hitchcock ${ }^{83}$ held that the validity of immunity statutes was dependent upon complete prosecutorial dispensation, rendering ineffective those provisos which guaranteed only that the testimony would not be used in a subsequent trial. ${ }^{84}$ Some state constitutions, in probable violation of the fourteenth amendment, ${ }^{85}$ presently purport to replace the privilege by the type of "immunity against use" provisions which the Court struck down in Counsel$\operatorname{man} .^{86}$

${ }^{82}$ Because a valid grant of immunity presupposes insulation from prosecution, the question has frequently arisen as to the necessity and power of the conferring jurisdiction to guarantee such insulation from prosecution in other jurisdictions. At an early date it was held that the federal government had the power to grant immunity from federal and state prosecution under the supremacy clause. Brown v. Walker, supra note 81, at 606-07; Ullmann v. United States, 350 U.S. 422, 429-31, 434-36 (1956). Furthermore, the policy and logic of Murphy v. Waterfront Comm'n, 378 U.S. 52 (1964), would seem to make immunity from state prosecution automatic when immunity is granted pursuant to federal statute. See United States v. Harris, 334 F.2d 460, 462 (2d Cir. 1964), rev'd, 382 U.S. 162 (1965).

Until Murphy, however, a state grant of immunity did not necessitate insulation from federal prosecution with respect to the matters under inquiry. In that case a state investigatory commission conferred immunity from state prosecution but the witness refused to answer the questions fearing possible federal prosecution. In reversing the subsequent contempt conviction, the Court remanded and ordered the witness to answer the questions but stipulated that the federal government could use neither the testimony so elicited nor its fruits. 378 U.S. at 79-80. A rule of exclusion apparently emerges from Murphy under which a state must confer immunity from prosecution under its own laws; and by so doing, it puts beyond the immediate reach of the federal government the information so obtained. Thus, while the witness need not (and cannot) be granted immunity from federal prosecution by the state, federal prosecution, in theory at least, will not be aided by operation of the state statute.

At present, however, there would appear to be no rule to prevent the use in one state of information elicited by another state by operation of an immunity statute. The most desirable solution to this problem is exemplified in the Illinois immunity act, which preconditions its operation on the absence of any threat of prosecution for matters testified about in all other jurisdictions. ILI. REv. STAT. ch. 38, § 106-4 (1964).

ss 142 U.S. 547 (1892).

as " $[N]$ o statute which leaves the ... witness subject to prosecution after he answers the criminating question put to lim, can have the effect of supplanting the privilege conferred by the Constitution of the United States." Id. at 585 .

${ }_{88}$ The following state constitutional provisions purport to sanction "immunity against use" only, but probably are invalid under Malloy v. Hogan, 378 U.S. 1 (1964) and Counselman v. Hitchcock, 142 U.S. 547 (1892): LA. CoNST., art. 19, § 13; PA. CoNST., art. 3, §32. But see State v. Rodrigues, 219 La. 217, 52 So. 2d 756 (1951), and Commonwealth v. Cameron, $229 \mathrm{~Pa} .592$, 79 Atl. 169 (1911), upholding these provisions on the authority of Twining v. New Jersey, 211 U.S. 78 (1908), which was implicitly overruled by Malloy v. Hogan, supra.

${ }^{80}$ Even before the extension of the fifth amendment doctrine of Counselman through the fourteenth amendment, the majority of states had concluded that under state self-incrimination guarantees the "immunity against use" statutes were invalid. E.g., People ex rel. Lewisohn v. O'Brien, 176 N.Y. 253, 68 N.E. 353 (1903); Commonwealth v. Frank, 159 Pa. Super. 271, 48 A.2d 10 (1946). 
Where the witness persists in his refusal to answer questions after a tender of immunity, the matter is referred to the court, which decides if the immunity is operative; upon a determination that immunity has been effectively granted, the witness may be ordered to answer. ${ }^{87}$ If the witness then continues to insist on the inefficacy of the immunity, he is subject to contempt proceedings for violation of the court's order. ${ }^{88}$

It is thus apparent that reliance upon the privilege against selfincrimination by the inexperienced grand jury witness presents a serious dilemma since an answer may expose the witness to severe hardships or penalties, while improper refusal to respond may result in punishment for contempt. ${ }^{80}$ The law of contempt may have special significance for the grand jury witness because of the procedural peculiarities involved. After the witness has claimed his privilege, been ordered by the judge to answer the questions, and returned to the grand jury room only to disregard the order, invocation of contempt proceedings are appropriate. ${ }^{.0}$ In the state courts

\footnotetext{
${ }^{87}$ Where the grand jury itself is empowered to confer immunity (see note 80 supra), immediate appeal to the court on the question of the applicability of the immunity provisions may be precluded so long as the immunity is in fact sufficient. People v. Riela, 9 App. Div. 2d 481, 195 N.Y.S.2d 558 (1959), remanded for resentencing, 7 N.Y.2d 571, 200 N.Y.S.2d 43 (1960); People v. Franzese, 24 Misc. 2d 355, 202 N.Y.S.2d 753 (Kings County Ct. 1960).

${ }^{88}$ E.g., Ullmann v. United States, 350 U.S. 422 (1955); Brown v. Walker, 161 U.S. 591 (1896). But see People v. Franzese, supra note 87, where a refusal to answer questions after the grand jury had conferred immunity constituted a completed contempt.

In New York it has been held that if a prospective defendant has reasonable grounds to believe that the grant of immunity is not complete, a refusal to answer is not punishable as a contempt. People v. DeFeo, 308 N.Y. 595, 127 N.E.2d 592 (1955) (reversing contempt conviction).

In order to confer immunity and supplant the privilege against self-incrimination, the state has the burden of showing the applicability of the immunity proviso. Stevens v. Marks, 383 U.S. 234, 244-46 (1966).

${ }^{89}$ The defendant in United States v. Winter, 348 F.2d 204, 210 (2d Cir.), cert. denied, 382 U.S. 955 (1965) (perjury conviction affirmed), envisioned himself on the horns of a "trilemma." Confronted with a blunt question as to his guilt or innocence, the defendant saw as his alternatives the distasteful choices of (1) admitting his guilt, (2) claiming the fifth amendment privileges and prejudicing the grand jury, or (3) lying and risking a perjury prosecution. He selected the third alternative but found the court unsympathetic to his plight.

${ }^{\circ}$ See, e.g., United States v. Harris, 382 U.S. 162 (1965); Brown v. United States, 359 U.S. 41, 49-50 (1959) (overruled by Harris); Hooley v. United States, 209 F.2d 219 (lst Cir. 1954). But see People v. Cochran, 307 Ill. 126, 138 N.E. 291 (1923); State v. Rodrigues, 219 La. 217, 52 So. 2d 756 (1951); Gendron v. Burnham, 146 Me. 387, 82 A.2d 773 (1951) (where the defendant was not sent back to the grand jury after being ordered by the judge to answer, but was immediately cited for contempt for persisting in refusal). Cf. State v. Rodrigues, supra, where the court observed: "The grand jury .. . is a constituent part, appendage, or arm of the court, and contempt committed
} 
where a summary contempt proceeding may result, the time lapse between these successive events may be very short indeed, and the line separating the contemptible act from the subsequent contempt proceeding may be transparent. ${ }^{91}$ Nevertheless, the witness is permitted time to consult with his counsel and may subsequently be allowed to purge himself of the contempt by answering. ${ }^{92}$

While the ability to confer with counsel before and during the "separate" contempt proceedings may partially shield the witness against compounding his adversity, other aspects of the contempt procedure may present new hazards. The judge may find the witness to be in criminal contempt and as a result many of the ordinary protections for criminal defendants are seriously diluted or entirely lost-this in spite of the fact that penalties may be quite severe. ${ }^{93}$

by a person in its presence is a direct contempt in the hearing and presence of-the court itself." 219 La. 234-35, 52 So. 2d at 759 (dictum).

${ }^{01}$ See, e.g., State v. Rodrigues, supra note 90; Gendron v. Burnham, supra note 90.

${ }^{02}$ Assistance from counsel should be available before the act of contempt has occurred. See Levine v. United States, 362 U.S. 610 (1960); Brown v. United States, 359 U.S. 41 (1959) (subsequently overruled on other grounds, see note 98 infra). However, a more mechanistic view has been adopted by some courts to justify the denial of counsel during this crucial time in which the defendant must determine his rights to his own satisfaction under the self-incrimination privilege. See, e.g., People v. Cochran, 307 IIl. 126, 138 N.E. 291 (1923) (before the completed contempt, appellant was a "witness," not a "defendant"); State v. Rodrigues, supra note 90 (same).

Several states have outlined a statutory procedure to be followed where a grand jury witness refuses to answer a question. Typically, the question and the refusal are put in writing and referred to the court. The judge then decides (apparently ex parte) whether the question ought to be answered and so informs the grand jury. If the witness is ordered to answer and persists in his refusal, he is brought before the court and dealt with as if he had refused to answer in open court. IND. ANN. STAT. $\$ \$ 9.822$ to -823 (1955); Mo. REv. Stat. $\$ \$ 540.190-.200$ (1949); NeB. REv. STAT. $\$ \S 29-1410$ to -1412 (1964); OHIO Rev. CODE ANN. $\$ \S 2939.14-15$ (Page 1953). Other states require that the witness appear before the court for a decision on the permissibility of the refusal. E.g, ARK. STAT. ANN. \$43-916 (1947); IowA CoDE $\$ 771.10$ (1962). By providing a hearing, California has adopted a scheme which most fully protects the witness against disclosing privileged matter and against punitive sanctions. CAL. PEN. CODE $\$ 1324$.

03 "[C]ontempts committed in the presence of the court, or so near thereto as to obstruct the administration of justice . . may be punished in conformity to the prevailing usage at law." 18 U.S.C. $\$ 402$ (1964). See Rogers v. United States, 340 U.S. 367 (1951) (affirming three-year sentence for criminal contempt conviction).

The recent case of Harris v. United States, 382 U.S. 162 (1965), would appear to raise an interesting question with regard to the permissible punishment for criminal contempt under $\$ 402$. FED. R. CRIM. P. 42 (a) authorizes a summary contempt conviction where (1) "the judge certifies that he saw or heard the [contemptible] conduct" and (2) the conduct occurred in the "actual presence" of the court. In Harris, the Court held that the use of summary contempt procedure in aid of a grand jury investigation was improper (see note 95 infra). The question is the extent to which testimonial contempts which are not punishable by summary procedure may be considered to 
Thus, a grand jury indictment ${ }^{94}$ or a petit jury verdict ${ }^{95}$ may not be retained as procedural requisites. Furthermore, since the time lapse from the completed contempt to the subsequent conviction may be quite short, the prospect of a public trial ${ }^{96}$ with due notice and the accompanying opportunity to prepare a defense ${ }^{07}$ may be obscured. However, a recent decision of the Supreme Court has rejected the practice in federal courts of using summary contempts to punish a witness for a wrongful refusal to answer questions under a claim of the fifth amendment. ${ }^{98}$

have been "committed in the presence of the court, or so near thereto as to obstruct the administration of justice" for purposes of the severe penalties of $\S 402$. The maximum penalty for contempts which do not fall within the above-quoted language is $\$ 1,000$ fine and six months imprisonment. 18 U.S.C. $\$ 402$ (1964).

As an alternative to criminal contempts, the court may cite the witness for civil contempt and order him incarcerated until he purges the contempt by answering the propounded queries. See Shillitani v. United States, 384 U.S. 364 (1966).

of Green v. United States, 356 U.S. 165, 184 (1958).

${ }^{95}$ E.g., People v. Burkert, 7 Ill. 2d 506, 510, 131 N.E.2d 495, 498 (1955).

The practice with respect to jury trials for criminals contemnors in federal courts has recently been modified. In Green v. United States, 356 U.S. 165 (1958), the Court declined to narrow the language of FED. R. Crsm. P. 42 (b) which provides, in part: "A criminal contempt except as provided in subdivision (a) [summary contempt] of this rule shall be prosecuted on notice .... The defendant is entitled to a trial by jury in any case in which an act of Congress so provides ...." Situations where the defendant in a contempt prosecution was entitled by statute to a trial by jury are set forth in 18 U.S.C. $\$ 3691$ (1964) (relating to certain criminal contempts) and 18 U.S.C. $\$ 3692$ (1964) (relating to contempts arising in labor disputes).

In Cheff v. Schnackenberg, 384 U.S. 373 (1966), as an exercise of its supervisory power over the federal courts but in language that smacked of constitutional interpretation, the Court ruled that before a defendant can be sentenced to six months or more for criminal contempt of a federal court, he is entitled to a trial by jury. Id. at 380 . However, in a companion case, Shillitani v. United States, 384 U.S. 364 (1966), the Court distinguished the criminal contempt from the civil contempt and held that where the condemnor has an "unqualified right to be released if and when he obeyed the order to testify," id. at $\mathbf{3 6 7}$, the contempt is civil in nature and hence requires no jury trial. Id. at 365 .

${ }^{\circ 6}$ See Levine v. United States, 362 U.S. 610 (1960). But cf. Cheff v. Schnackenberg, supra note 95; Harris v. United States, 382 U.S. 162 (1965).

${ }^{97}$ E.g., Gendron v. Burmham, 146 Me. 387, 402-03, 82 A.2d 773, 783 (1951). Cf. State v. Granchay, 1 Ohio App. 2d 307, 204 N.E.2d 562 (1964).

At some point, a combination of aggravating factors which deprive the defendant of counsel, a public trial, and an opportunity to prepare a defense may exceed the bounds of due process. In re Oliver, 333 U.S. 257 (1948).

${ }^{28}$ In Brown v. United States, 359 U.S. 41 (1959), the Court sanctioned the power of a federal court to convict a witness summarily "in aid of a grand jury investigation" under FED. R. CRIM. P. 42 (a). In Brown the recalcitrant witness was taken from the grand jury and escorted before the judge where he was ordered to answer the ques. tions in response to which lie had initially claimed the privilege. The contempt citatation followed a renewed refusal, and a subsequent motion for a later hearing on the contempt charge under FED. R. CriM. P. 42 (b) was held to have been properly denied. In Harris v. United States, 382 U.S. 162 (1965), the Court expressly overruled Brown and lield that unless the defendant's conduct imperiled the order of the proceeding or 


\section{B. Other privileges}

In addition to self-incrimination, the witness may be able to rely on certain other privileges. While the grand jury witness is not allowed to interpose objections to questions on the grounds of strict evidentiary rules insuring relevance ${ }^{99}$ or probity, ${ }^{100}$ he may be able to avoid answering by invoking applicable common law or statutory privileges. A refusal to answer is justified where the information sought is protected from disclosure by the husband-wife privilege, ${ }^{101}$ the attorney-client privilege, ${ }^{102}$ the physician-patient privilege, ${ }^{103}$ or other similar rules guarding against revelation or protecting relationships. ${ }^{104}$

affronted the dignity of the court, prosecution for contempt should proceed under rule 42 (b), i.e., not summarily. The holding in Harris, however, is limited to contempt proceedings under the Federal Rules, apparently leaving the use of summary contempts in state courts intact. See Note, 1966 DUKE L.J. 814.

${ }^{20}$ The objection of irrelevance raised by a grand jury witness must rest on the assumption that the matter under inquiry is beyond the grand jury's jurisdiction to investigate. Conceivably, this objection might succeed, especially where the immediate purpose of the investigation is limited, as in the case of the so-called "special" grand jury. However, since the breadth of the grand jury's proper scope is often unlimited (see note 22 supra and accompanying text), an objection on the grounds of irrelevancy will probably fail. Thus, it has been said that "the scope of [the grand jury's] ... powers may not be cut down by the witness. The identity of the offender and the precise crime involved will normally be developed at the end rather than the beginning of its labors." Orfield, The Federal Grand Jury, 22 F.R.D. 343, 395 (1959).

${ }^{200}$ See Costello v. United States, 350 U.S. 859 (1956) (holding valid an indictment based entirely on hearsay evidence). There the Court stated that "if indictments were to be held open to challenge on the ground that there was inadequate or incompetent evidence before the grand jury, the resulting delay would be great indeed. The result of such a rule would be that before trial on the merits a defendant could always insist on a kind of preliminary trial to determine the competency and adequacy of the evidence before the grand jury. This is not required by the Fifth Amendment. An indictment returned by a legally constituted and unbiased grand jury, like an information, if valid on its face, is enough to call for the trial of the charge on the merits." Id. at 363. A substantial number of states reject this position. See note 23 supra. ${ }_{201}$ E.g., Blau v. United States, 340 U.S. 332, 333-34 (1951); United States v. Remington, 208 F.2d 567, 572-73 (2d Cir. 1953) (dissenting opinion), cert. denied, 347 Ụ.S. 913 (1954).

${ }_{102}$ United States v. Judson, 322 F.2d 460 (9th Cir. 1963) (involving subpoena duces tecum); Schwimmer v. United States, 232 F.2d 855 (8th Cir.) (court found waiver), cert. denied, 352 U.S. 833 (1956); United States v. Lee, 107 Fed. 702 (C.C.E.D.N.Y. 1901) (communication not within privilege); Ex parte McDonough, 170 Cal. 230, 149 Pac. 566 (1915); Ex parte Bruns, 15 Cal. App. 2d 1, 58 P.2d 1318 (Dist. Ct. App. 1936) (communication not within privilege).

In New York the same recognition of statutory privileges is assured by the statutory "legal evidence" rule set out in note 23 supra. People ex rel. Vogelstein v. Warden, 150 Misc. 714, 270 N.Y. Supp. 362 (Sup. Ct.) (by implication), aff'd, 242 App. Div. 611, 271 N.Y. Supp. 1059 (1934).

${ }_{108}$ E.g., Application of Grand Jury, 286 App. Div. 270, 143 N.Y.S.2d 501 (1955).

${ }^{10}$ Certainly the policies which support the various statutory privileges would not 
The full enjoyment of these statutory privileges by the witness may be effectively precluded because of the special circumstances of the grand jury context. First, the absence of the person to whom the privilege belongs may debilitate its diligent exertion. ${ }^{105}$ Second, the secrecy of the grand jury proceeding may undermine the policy of the privilege and make it inapplicable. ${ }^{108}$ Finally, the absence of the judge at the grand jury session may remove an important defender of these privileges. ${ }^{107}$

\section{Right to counsel}

Considering the susceptibility of the witness' rights to erosion and the dangers which a misplaced reliance on these rights may involve, it is evident that a grand jury appearance may represent a serious threat to the uninformed witness. The important values supporting the witness' rights, as well as the witness' interest in freedom from conflict with the authority of the court, would certainly be more securely insured if counsel were afforded during testification to advise the witness of the legal intricacies which his appearance might involve.

American courts have consistently held that the scope of a "criminal prosecution," for purposes of the sixth amendment's guarantee of counsel, does not encompass the grand jury proceeding. ${ }^{108}$ De-

justify a distinction between testimony given at trial and that given before a grand jury. Since, as Professor McCormick has observed, "their sole warrant is the pro. tection of interests and relationships which ... are regarded as of sufficient social importance to justify some incidental sacrifice of sources of facts needed in the admin. istration of justice," the privileges' purposes may be defeated by any disclosure which is compelled by and before the government. See Annot., 133 A.L.R. 732 (1941). For an express statutory provision recognizing privileged communications, see Mich. STAT. ANN. $\$ 28.945$ (1) (1954).

${ }^{105}$ See, e.g., United States v. Remington, 208 F.2d 567, 572-73 (2d Cir. 1953) (dissenting opinion), cert. denied, 347 U.S. 913 (1954); Wickline v. Alvis, 103 Ohio App. 1, 144 N.E.2d 207 (1957).

${ }^{100}$ The trade secrets privilege is one such privilege subject to vitiation because the grand jury operates in seclusion. Application of Radio Corp. of America, 13 F.R.D. 167, 172 (S.D.N.Y. 1952) (involving subpoena duces tecum).

Professor Wigmore has observed: "The simple expedient of restricting the disclosure to the judge or his delegate will usually prevent whatever detriment might otherwise be incurred by forcing a public revelation of the trade secret." 8 Wigmore $\$ 2212$. Thus, the policy factors of the privilege are absent in the context of the in camera grand jury.

${ }^{107}$ See McCormick $\$ 73$, at 153, where the author refers to the "usual willingness of trial courts of their own motion to safegnard the privileges."

${ }^{108}$ E.g., In re Groban, 352 U.S. 330, 333 (1957) (dictum); Counselman v. Hitchcock, 142 U.S. 547, 563 (1892) (dictum); Gilmore v. United States, 129 F.2d 199, 203 (10th Cir.), cert. deniéd, 317 U.S. 631 (1942); In re Black, 47 F.2d 542, 543 (2d Cir. 1931); 
veloped at a time when the scope of the criminal prosecution was viewed as limited to the trial itself, this rule was thought to prevent the grand jury from becoming a preliminary adjudicatory forum in which various formalities could be injected to obstruct orderly prosecutions. The courts treated requests for the benefit of counsel by indicted defendants as broad assertions that the grand jury proceeding was a step in the criminal prosecution amounting to a part of the criminal trial. ${ }^{109}$ No clear attempt was made to distinguish the de jure or de facto defendant from one who had been indicted by the grand jury but had not been a witness before that body.110 Thus, in rejecting the defendant's objection that his indictment was fatally defective because he was denied representation by counsel before the grand jury, the courts denied alike the related sixth amendment rights to face one's accusers and to present evidence in defense. ${ }^{111}$ The reasons given for excluding the attorney of the person being investigated are obvious: the grand jury proceedings should not be a full-scale preliminary trial to the detriment of the public interest in speedy adjudication; ${ }^{112}$ the presence of the accused's

United States v. Grunewald, 164 F. Supp. 640, 641 (S.D.N.X. 1958); United States v. Blanton, 77 F. Supp. 812, 816 (E.D. Mo. 1948); People v. Dale, 79 Cal. App. 2d 370, 376, 179 P.2d 870, 873 (Dist. Ct. App. 1947); State v. Stallings, 25 Conn. Supp. 386, 389, 206 A.2d 277, 278 (Super. Ct. 1964); Ferris v. Lockett, I75 Kan. 704, 712, 267 P.2d 190, 197, rev'd per curiam sub nom. Courtney v. Schroeder, 348 U.S. 933 (1955). Cf. Anonymous v. Baker, 360 U.S. 287 (1959); FED. R. CRIM. P. 6 (d) (clearly requires that counsel be excluded from the grand jury room). But see Cadle v. State, 101 Ga. App. 175, 113 S.E.2d 180 (1960), involving a statute extending additional safeguards to the grand jury proceeding in cases of alleged misfeasance in public office.

At present, only one court appears to have allowed the witness to consult his counsel during the grand jury proceeding as a matter of constitutional right. People v. Taniello, 35 U.S.L. WeEk 2003 (N.Y. Sup. Ct. June 24, 1966).

${ }^{200}$ Indicative of this approach is the distinction drawn in Counselman v. Hitchcock, 142 U.S. 547 (1892), where the Court held the fifth amendment privilege against selfincrimination applicable to the grand jury but rejected in dicta the contention that such a conclusion would necessitate application of sixth amendment rights to the same proceeding.

The Court stated that the right to counsel provision refers to "a criminal prosecution against a person who is accused and who is tried by a petit jury. A criminal prosecution under article 6 of the amendments, is much narrower than a 'criminal case,' under article 5 of the amendments." Id. at 563.

${ }^{210}$ Obviously, one who is indicted may or may not have been a witness just as a witness need not have been indicted. One who is both a witness and is subsequently indicted may in turn he a de jure, de facto, or potential defendant. As to the latter classification, see notes 56-59 supra and accompanying text.

${ }^{121}$ In re Black, 47 F.2d 542 (2d Cir. 1931); State v. Stallings, 25 Conn. Supp. 386, 206 A.2d 277 (Super. Ct. 1964). See also notes 18-20 supra and accompanying text.

${ }^{112}$ See, e.g., United States v. Grunewald, 164 F. Supp. 640, 642 (S.D.N.Y. 1958). This objection may assume that the presence of accused's counsel would be an invitation to a preliminary trial. 
counsel would jeopardize the valuable incidents of grand jury secre$c y ; ;^{113}$ the grand jury does not adjudicate guilt; $;^{114}$ the presence of the accused's counsel would hamper the freedom of the grand jury and the prosecutor in their investigation; $; 15$ and the establishment of the identity of the accused may often not be made until some later point in the course of the investigation. ${ }^{116}$ The shorthand conclusion based upon the foregoing premises has been that the grand jury proceeding is not part of the criminal prosecution within the meaning of the sixth amendment. ${ }^{117}$

In denying the right to counsel during the grand jury proceeding, the courts deprived the defendant of a sword with which he could sabotage the machinery of justice. However, the rule has been extended to the distinguishable situation in which a witness (whether subsequently indicted or not) seeks to employ counsel as a shield during testification. ${ }^{118}$ Where the witness asserts the right to be accompanied by counsel, many of the reasons set forth for denying this advantage to the person under indictment are inoperative. It is unlikely that the presence of the witness' attorney would result in undue delay ${ }^{119}$ or that any of the valid policy reasons supporting the

113 Many of the reasons given in note 24 supra for the secrecy requirement would seem to dictate that defendant's counsel be excluded.

${ }^{214}$ See, e.g., State v. Guay, 25 Conn. Supp. 61, 65, 196 A.2d 599, 601 (Super. Ct. 1963). But cf. observation of Judge Frank, note 41 supra.

II5 Allowing the accused's counsel to be present during the grand jury proceedings would certainly "open up knowledge of the government's case," a result inconsistent with the dictates of policy. See States v. Smyth, 104 F. Supp. 283, 304 (N.D. Cal. 1952).

${ }^{218}$ The fact that accusations by the grand jury are often the end products of the investigation would make impossible the extension of adversary rights to the accused. See comments by Professor Orfield, note 99 supra.

${ }^{112}$ See, e.g., Gilmore v. United States, 129 F.2d 199, 203 (10th Cir.), cert. denied, 317 U.S. 631 (1942); Ferris v. Lockett, 175 Kan. 704, 712, 267 P.2d 190, 197 (1954), rev'd per curiam sub nom. Courtney v. Schroeder, 348 U.S. 933 (1955).

${ }^{218}$ In re Black, 47 F.2d 542 (2d Cir. 1931). "But the privilege against self-incrim. ination is personal. Neither at a trial nor before a grand jury is he entitled to have the aid of counsel when testifying . . . . A witness is not entitled to be furnished witl facilities for evading issues or concealing true facts." Id. at 543 . See also United States v. Grunewald, 164 F. Supp. 640 (S.D.N.Y. 1958). But cf. Kitchell v. United States, 354 F.2d 715, 720 (1st Cir. 1965), cert. denied, 384 U.S. 1011 (1966) (distinguished Escobedo); United States v. Irwin, 354 F.2d 192, 199 (2d Cir. 1965), cert. denied, 383 U.S. 967 (1966); United States v. Winter, 348 F.2d 204, 208 (2d Cir.), cert. denied, 982 U.S. 955 (1965) (even if Escobedo applied, denial of right to counsel would not cure perjury).

${ }^{210}$ In light of the "valid-on-its-face" doctrine of Costello v. United States, 350 U.S. 359, 363 (1956) (note 100 supra), it cannot be said that counsel for the witness could delay the proceeding, since technical grounds for objections are not permitted. See also note 93 supra. Some delay might result from counsel's assistance in urging the invocation of apphicable privileges, but the policy factors supporting these privileges would seem to warrant the slight inconveniences necessary to preserve them. Certainly 
secrecy requirement would be subverted. ${ }^{120}$ While it is probable that the presence of the witness' counsel might inhibit the investigatory freedom of the prosecutor and the grand jury, to the extent that this freedom is purchased at the direct expense of the witness its value is highly questionable. ${ }^{121}$

Recognizing the special dangers which compulsory appearance without counsel poses for the grand jury witness who is also a prospective defendant, many jurisdictions have pursued courses of action which allay these threats to some degree. In some states de jure and de facto defendants cannot be called ${ }^{122}$ and in others this practice is permitted but not encouraged. ${ }^{123}$ Still other jurisdictions permit the witness' counsel to wait in an adjoining room to advise his client during periodic recesses which are liberally granted for this very purpose. ${ }^{124}$ Only Michigan has abandoned the no-counsel

this judgment would appear valid in view of the fact that the law presently regards the privileges highly enough to allow them to obstruct the search for truth at the threshold of inquiry.

${ }^{120}$ The presence of the witness' counsel, who, for conceptual clarity and due to the identity of interests, can be considered his alter ego, would not appear to threaten the accomplishment of secrecy policies enumerated in note 24 supra. While the presence of counsel might inhibit some disclosures, he could only do so where the law already, for one reason or another, recognizes the paramount right of the witness not to answer.

It has been argued that allowing the witness' counsel to attend could subvert the objectives of a grand jury investigation of a criminal group, the members of which all have the same lawyer. Enker \& Elsen, Counsel for the Suspect: Massiah v. United States and Escobedo v. Illinois, 49 MiNN. L. REv. 47, $74 \mathrm{n} .84$ (1964). However, the witness is generally not prevented by oath from disclosing the nature of his testimony. See note 27 supra. In any event, serious constitutional questions would arise where a secrecy oath was interpreted to prohibit a witness from telling his own counsel the nature of his grand jury testimony. See Goodman v. United States, 108 F.2d 516, 520-21 (9th Cir. 1939) (dictum); ILL. Rev. Stat. ch. 38, § 112.6 (Supp. 1965) (by implication, allows the witness to divulge the content of his testimony).

${ }^{221}$ Counsel for the witness could be expected to discourage the prosecutor's efforts to acquire privileged information, but it is exactly this effort which the law condemns in recognizing the privilege. To create privileges and at the same time inhibit their effective use is paradoxical indeed.

Any proposed extension of the witness' right to counsel would certainly meet immeasurable, and conceivably irrational, opposition from prosecutors who dearly prize their preferred relationship with the grand jury. Another lawyer in the room might be considered a threat to the control and influence the prosecutor could wield. However, it is a common criticism of the grand jury that it has already been allowed to fall prey to the prosecutor's control. See Note, 72 YALE L.J. 590, 592-93 (1963). But see United States v. Smyth, 104 F. Supp. 283, 301 (1952).

122 See note 32 supra and accompanying text.

${ }^{123}$ See, e.g., United States v. Scully, 225 F.2d 113, 116 (2d Cir.), cert. denied, 350 U.S. 897 (1955); Gendron v. Burnham, 146 Me. 387, 397, 82 A.2d 773, 780-81 (1951); Burke v. State, 104 Ohio St. 220, 231, 135 N.E. 644, 647 (1922).

${ }^{124}$ See, e.g., Levine v. United States, 362 U.S. 610 (1960); Kitchell v. United States, 354 F.2d 715, 720 n.9 (1st Cir. 1965), cert. denied, 384 U.S. 1011 (1966); United States 
rule by statute to permit a witness to be accompanied by his attorney while testifying. ${ }^{125}$

While decisions holding that the grand jury proceeding is not per se a part of the sixth amendment's criminal prosecution appear sound, it does not follow that a grand jury proceeding is per se not a part of the "criminal prosecution" as that concept has been developed in recent Supreme Court decisions. From the standpoint of the grand jury witness who is either marked for prosecution prior to the proceeding or is singled out during its course, the criminal prosecution for purposes of the sixth amendment would already seem to have commenced. In this connection, an analysis of three recent Supreme Court decisions-In re Groban, ${ }^{126}$ Escobedo $v$. Illinois, ${ }^{122}$ and Miranda v. Arizon $a^{128}$-is especially relevant.

In Groban a divided Court held that a witness under subpoena did not have a constitutional right to be assisted by counsel during interrogation by a state fire marshal who was required by statute to investigate the causes of fires. ${ }^{129}$ Over a vigorous dissent, the Court held that there was no right to counsel because the investigation was not a "criminal prosecution" within the meaning of the sixth amendment. ${ }^{130}$ To the majority, the gravamen of a "criminal prosecution" was the adjudication of rights and liabilities, and thus a witness in a proceeding in which no legal relationships were formally

v. Tramunti, 343 F.2d 548 (2d Cir. 1965); United States v. Grunewald, 164 F. Supp. 640, 641 (S.D.N.Y. 1958). In People v. Ianiello, 35 U.S.L. WEEK 2003 (N.Y. Sup. Ct. June 24, 1966), the failure to allow the witness to consult with his counsel was held to have been a violation of the witness' constitutional right.

125 "Any person called before the grand jury shall at all times be entitled to legal counsel not involving delay and he may discuss fully with his counsel all matters relative to his part in the inquiry without being subject to a citation for contempt. The witness shall have the right to have counsel present in the room where the inquiry is held." Mich. STat. ANN. $\$ 28.943$ (Supp. 1965). Both the witness and his counsel are sworn to secrecy. Ibid.

It should be noted that the additional safeguards afforded by Michigan are probably not altogether unrelated to the notorious "one-man grand jury" institution of that jurisdiction. See In re Oliver, 333 U.S. 257 (1948); Scigliano, Inquisitorial Proceedings and Separation of Functions: the Case of the Michigan One-Man Grand Jury, 38 U. DET. L.J. 82 (1960).

${ }^{120} 352$ U.S. 330 (1957).

127378 U.S. 478 (1964).

128384 U.S. 436 (1966).

120 The fire marshal also had the power to initiate a criminal prosecution by filing an information against suspected arsonists. Ohio Gen. \& Local Acts 1902, No. 872, \$409-52, at 472 (now OHio REv. CODE ANN. \$3737.10 (Page Supp. 1965)).

130352 U.S. at 332 . 
determined was not entitled to the benefit of sixth amendment guarantees. ${ }^{131}$

In certain respects the approach taken by $\mathrm{Mr}$. Justice Black in his dissent is similar to that adopted by the majority eight years later in Escobedo. ${ }^{132}$ Justice Black did not dwell extensively upon the power of the marshal to initiate prosecutions ${ }^{133}$ nor did he rely upon a mechanistic distinction between an in camera administrative hearing and a trial..$^{134}$ Rather, he emphasized the characteristics of the hearing in which the appellant found himself. The dissent stressed the adverse consequences which might follow from making a lay witness exercise his right against self-incrimination unaided by counsel,,$^{135}$ and underscored the danger of inadvertent or ignorant self-exposure inherent in compulsory uncounseled testification. ${ }^{136}$ These considerations led the minority to conclude:

The Due Process Clause requires that a person interrogated be allowed to use legal counsel whenever he is compelled to give testimony to law-enforcement officers which may be instrumental in his prosecution and conviction for a criminal offense. ${ }^{137}$

Clearly the evils the dissenters envisioned in Groban may be present in the grand jury proceeding. However, Mr. Justice Black expressly disavowed the possibility that he would have extended the right of counsel to one who (in other respects similarly situated to Groban) was compelled to testify before a grand jury. ${ }^{138} \mathrm{He}$ distinguished the grand jury situation from the facts in Groban on the grounds that the grand jury, unlike the fire marshal, was less concerned with securing convictions than with protecting its fellow citizens. ${ }^{139}$ Such an assumption, when applied indiscriminately to

181 "Prosecution of an individual differs widely from administrative investigation of incidents damaging to the economy or dangerous to the public. The proceeding before the Fire Marshal was not a criminal trial, nor was it an administrative proceeding that would in any way adjudicate appellants' responsibilities for the fire." Ibid.

${ }^{183}$ See text accompanying notes $143-44$ infra.

${ }^{138}$ Cf. Anonymous v. Baker, 360 U.S. 287, 298 (1959) (Black, J., dissenting).

186 "The right to use counsel at the formal trial is a very hollow thing when, for all practical purposes, the conviction is already assured by pretrial examination." 352 U.S. at 344 .

185 Id. at 345.46 .

$180 \mathrm{Id}$. at 344 .

187 Ibid.

${ }^{138} I d$. at $346-47$.

180 "[A]ny surface support the graud jury practice may lend disappears upon analysis of that institution .... [The graud jurors] ... bring into the grand jury room the experience, knowledge and viewpoint of all sections of the community ... [T]he 
every grand jury under the guidance of a prosecuting attorney, would seem to be excessively optimistic and quite untenable. ${ }^{140}$ Therefore, despite the dicta concerning the grand jury situation, it is reasonable to conclude that with the rejection of In re Groban the grand jury witness's right to counsel might be recognized.

For several reasons it would appear that In re Groban has been sapped of its vitality by Escobedo v. Illinois, which in turn has been reinforced by Miranda $v$. Arizona. In addition to the fact that the four dissenting justices in Groban constituted four-fifths of the majorities in Escobedo and Miranda, ${ }^{141}$ the Court in Escobedo cited the dissent in Groban for the broad public policy dictating a need for counsel during a "pretrial examination."142 Moreover, the underpinnings of Groban cannot be reconciled with the assumptions underlying or the objectives behind the more recent Court pronouncements. ${ }^{143}$

In Escobedo the defendant was convicted of a capital offense after a trial during which the court admitted a "voluntary" confession ${ }^{144}$ procured by the police after extended questioning. ${ }^{145}$

presence of the jurors offers a substantial safeguard against officers' misrepresentation, unintentional or otherwise, of witness' statements and conduct before the grand jury." Ibid. Accord, Hannah v. Larche, 363 U.S. 420, 498 (1960) (Douglas, J., dissenting); Costello v. United States, 350 U.S. 359, 362 (1956).

${ }_{110}$ The attitude which gives the grand jury the conclusive benefit of all doubts would appear, both in the light of grand jury tactics revealed in the casees and upon a closer examination of the operations of that body, to be naive and unrealistic. See United States v. Remington, 208 F.2d 567, $571-72$ (2d Cir. 1953) (Hand, L., J., dissenting), cert. denied, 347 U.S. 913 (1954); Coates, The Grand Jury, the Prosecutor's Puppet, 33 PA. B.A.Q. 311,315 (1962). It appears to overlook the following practices:

(I) Failing to warn witnesses, whether suspected or not, of their privilege against self-incrimination, see note 66 supra;

(2) Permitting the active participation of the prosecuting attorney, who may well be interested in obtaining convictions, in the grand jury investigation, see note 121 supra; and

(3) Calling prospective defendants to interrogate thein under oath about crimes they are suspected of having committed, see note 31 supra and accompanying text. See also United States v. Bergman, 354 F.2d 931 (2d Cir. 1966); United States v. Rosen, 353 F.2d 523 (2d Cir. 1965), cert. denied, 383 U.S. 908 (1966); United States v. Winter, 348 F.2d 204 (2d Cir.), cert. denied, 382 U.S. 955 (1965), epitomizing the abuses of the inquisitorial tactics of some grand juries. In those cases, the defendants were asked under oath if they committed named criminal acts. The denials in response led to perjury convictions.

141 Justices Black, Douglas, Warren and Brennan.

142378 U.S. at $487-88$ (quoting the passage set forth in note 134 supra).

143 See note 151 infra and accompanying text.

14 This finding of fact based upon the unchallenged standards adopted by the lower court was not disturbed. Thus, the particular elements of coercion present in the case would appear to have been of only peripheral siguificance to the decision.

${ }^{145}$ The interrogation continued for more than fourteen hours. 
Escobedo was not informed of his privilege against self-incrimination, ${ }^{146}$ and although he asked to see his lawyer, ${ }^{147}$ his request was denied until the confession had been obtained.

The Court, through Mr. Justice Goldberg, reached its holding in guarded language, with the issue framed narrowly:

[Whether], under the circumstances, the refusal by the police to honor petitioner's request to consult with his lawyer during the course of an interrogation constitutes a denial of "the Assistance of Counsel" in violation of the Sixth Amendment to the Constitution as "made obhgatory upon the States by the Fourteenth Amendment .... 148

The "circumstances" referred to were delineated with care and fully elaborated. ${ }^{149}$ This caution, reflected in the particularistic treatment of the facts, has left a persistingly troublesome cloud over the scope of the holding. ${ }^{150}$

\footnotetext{
240 378 U.S. at 485.

${ }^{267}$ Defendant's counsel also asked to see the accused but his request was refused. See State v. Swiger, 5 Ohio St. 2d 151, 161, 214 N.E.2d 417, 425 (1966), where this element of Escobedo was deemed controlling. The Court in Miranda felt that this was a pure sixth amendment violation. 384 U.S. at $465 \mathrm{n} .35$.

110378 U.S. at 479.

${ }^{210}$ Among the particular "circumstances" the court may have been referring to are
} the following:

(1) The period of detention;

(2) Request for counsel; see State v. Swiger, 5 Ohio St. 2d 151, 161, 214 N.E.2d 417, 42,5 (1966).

(3) Availability of the lawyer;

(4) The inexperience of defendant, a twenty-two-year-old of Mexican extraction;

(5) The use of a Spanish-speaking officer to coax a confession;

(6) The false promise that he could go home if he confessed;

(7) The calculation with which the confession was produced; and

(8) The failure to warn defendant of his privilege against self-incrimination. See People v. Treloar, 64 Cal. 2d 145, 410 P.2d 620 (1966).

${ }_{150}$ See, e.g., Edwards v. Holman, 342 F.2d 679 (5th Cir. 1965); Wright v. Dicksou, 336 F.2d 878 (9th Cir. 1964); Queen v. United States, 335 F.2d 297 (D.C. Cir. 1964). See also Miranda $v$. Arizona, 384 U.S. at 440 , where the Court, referring to the Escobedo aftermath says: "[Escobedo] has been the subject of judicial interpretation and spirited legal debate since it was decided two years ago. Both state and federal courts, in assessing its implications, have arrived at varying conclusions."

Even after Miranda, the precise meaning of Escobedo is of more than mere historical or academic interest. Most obviously, the Court's decision in Johnson v. New Jersey, 384 U.S. 719 (1966), which requires only a prospective application of Miranda and Escobedo, Ienders the Escobedo case of extreme importance to a multitude of defendants whose cases were pending during the two year interim. Moreover, to the extent that the less definite language or broad policies of Escobedo may more severely restrict investigatorial examinations in a certain case than the relatively precise directions of Miranda, the more restrictive result is probably commanded. It is clear that the intent of the Court in Miranda was to "adhere to the principles of Escobedo ...." 384 U.S. at 444. 
Notwithstanding the narrow statement of the issue and the particularized treatment of the facts, there is ample and convincing language in the opinion to indicate that the decision was intended to have a liberal rather than a restrictive scope. It is instructive to note that the stated evil to be avoided was the growth of "a system of criminal law enforcement which comes to depend on the "confession' "151 and the concomitant "cynical prosecutor" who takes the attitude:

Let them have the most illustrious counsel now. They can't escape the noose. There is nothing that counsel can do for them at trial. ${ }^{152}$

It was apparently in furtherance of these policy objectives that the Court concluded:

[W] hen the process shifts from investigatory to accusatory-when its focus is on the accused and its purpose is to elicit a confessionour adversary system begins to operate, and ... the accused must be permitted to consult with his lawyer. ${ }^{153}$

The liberal reading of Escobedo is convincingly supported by the recent amplification and extension of that decision in Miranda $v$. Arizona. In the latter case the Court explained what it had meant in Escobedo by an "investigation which had focused on an accused." Focusing occurs when the investigation takes the form of a "custodial interrogation," which refers to "questioning initiated by law enforcement officers after a person has been taken into custody or otherwise deprived of his freedom of action in any significant way."154 Interpreted literally, this language sweeps into its protective ambit the grand jury witness or the witness before the fire marshal. Furthermore, where the witness is a de facto or de jure defendant, his dilemma exceeds that of the accused in police custody.

The single most perplexing question raised by Escobedo and Miranda, insofar as those decisions might bolster the rights of a grand jury witness, is whether actual police custody is an essential ingredient to their application. The Court in Miranda emphasized the innately coercive and highly disarming environment provided

181378 U.S. at $488-89$.

${ }^{162} I d$. at 488.

${ }^{263} \mathrm{Id}$. at 492.

154384 U.S. at 444. 
by the station house. It also stressed the highly developed, psychologically persuasive tactics employed by skilled police interrogators which were used to elicit confessions. Therefore, the Court concluded that in order to assure that confessions were the product of free choice consistent with the guarantees of the fifth amendment, the assistance of counsel must be provided. ${ }^{155}$ In contrast, the grand jury witness is confronted by a prosecuting attorney and a group of his peers under distinguishable circumstances.

However, the distinction may be without difference, and the situation of the grand jury witness may be far more precarious than that of his station house counterpart. Unable to rely on any privilege of absolute silence, and caught between the Scylla of contempt or perjury and the Charybdis of indictment, the witness at the closeddoor inquisition may find it much more difficult to assert effectively his privilege against self-incrimination. Furthermore, one may speculate that the psychological pressures operative on the witness are no less significant. The disarming officiousness of the grand jury, the fear of indictment, the misplaced confidence in fellow laymen acting under the direction of a conviction-minded prosecutor, the awareness of the law of contempt, and the possible uncertainty as to the legal limits of invoked immunity statutes all severely complicàte a witness' decision to respond to questions which demand incriminating answers.

It is also doubtful from the holding in Miranda itself that the aggravating circumstances assumed to exist in the police station must in fact obtain before the constitutional guarantees enunciated in those cases are available. Thus, the Court did not qualify its holding by exempting from the exclusionary rule statements made to untrained police or statements elicited without the use of psychological pressures. It would appear to follow that the Court, in prescribing the blanket assistance of counsel rules, was concerned with the possibility of unfairness rather than with the degree of abuse in a particular case. It is submitted that the possibility for abusing the rights of the grand jury witness is similarly great and should dictate the same result.

The Court made it clear in Miranda that in addition to pro-

168 The Court noted that in effectively protecting the right of silence, the presence of counsel would also "insure that statements made in the government-established atmosphere are not the product of compulsion." Id. at 466. 
viding counsel to fortify the fifth amendment privilege, the sixth amendment guarantee of counsel is involved in a custodial interrogation. Where, as in Escobedo, the defendant is denied access to his lawyer during the questioning, his sixth amendment rights are abridged. ${ }^{156}$ It is further evident from the facts of Escobedo that the right to counsel may arise at a point in time before indictment. ${ }^{157}$ Moreover, where the right to counsel has already attached in the police station after the "criminal prosecution" commences, the unanswered question is whether the right to counsel and the criminal prosecution temporarily cease while the future defendant is compelled to appear before the grand jury to answer under oath the questions of the prosecutor. None of the policy factors supporting the rule excluding a witness' counsel from grand jury proceedings would seem so strong as to dictate the creation of such a gap. ${ }^{168}$

\section{ConcLuSION}

For the grand jury witness to maximize his self-interest during a compulsory appearance may be a difficult task. Where the witness apprehends danger in the probings of the grand jury, he must often rely on the privilege against self-incrimination, which is subject to waiver ${ }^{169}$ as well as loss through a grant of immunity. ${ }^{180}$ The witness may also adversely affect his own future criminal defense by supplying evidence which can be used for impeaching his testimony at trial. ${ }^{101}$ In addition, the witness may be unaware that information he is asked to give is protected by an applicable statutory

260 Id. at 465 n.35.

${ }^{267}$ See Greenwell v. United States, 336 F.2d 962 (D.C. Cir.), cert. denied, 380 U.S. 923 (1964). See also White v. Maryland, 373 U.S. 59 (1963) (per curiam) (at arraignment).

This "point in time" factor appeared crucial to Mr. Justice Stewart in dissent: "Under our system of criminal justice the instigation of formal, meaningful judicial proceedings, by way of indictment, information, or arraignment, marks the point at which criminal investigation commenced." 378 U.S. at 493-94.

${ }^{258}$ In Massiah v. United States, 377 U.S. 201 (1964), the Court held that incrim. inating information acquired by means of electronic eavesdropping after defendant had been indicted and while he was awaiting trial was procured in violation of the right to counsel. The opinion seems to proceed on the theory that once the right of counsel has accrued, it inheres until after trial.

Cf. Miranda v. Arizona, 384 U.S. 436, 470 (1966). "Thus, the need for counsel to protect the Fifth Amendment privilege comprehends not merely a right to consult with counsel prior to questioning .... if the defendant so desires."

${ }^{150}$ See notes 74-78 supra and accompanying text.

${ }^{150}$ See notes 80.85 supra and accompanying text.

${ }^{201}$ See notes 60-64 supra and accompanying text. 
privilege. ${ }^{162}$ Furthermore, the witness who is also an object of the investigation must keep in mind the effect his conduct may have in his endeavor to avoid being indicted. Finally, the grand jury witness must be fully cognizant of the law of contempt ${ }^{163}$ and warned against perjuring himself to conceal incriminating information. ${ }^{164}$ For the uninformed layman, the full enjoyment of these rights may be quite difficult to obtain and efforts to exercise them may lead to serious sanctions.

To fortify the existing rights of grand jury witnesses in keeping with recent developments expanding the criminal defendant's constitutional rights, various courses are now open to the courts:

(1) The rule, based on the privilege against self-incrimination, immunizing prospective defendants from grand jury appearances may be more generally adopted. ${ }^{185}$ This rule, however, may not provide the best solution to the problem. Besides preventing the prospective defendant from testifying in a way so as to nip his accusation and possible prosecution in the bud, ${ }^{168}$ it is not broad enough in its immunization. Under this rule de jure and sometimes de facto defendants are immunized from appearance; however, a suspicion of the witness' criminality may first occur during the questioning, as in the case of a merely potential defendant. ${ }^{167}$ When this occurs,

\footnotetext{
102 See notes 101-07 supra and accompanying text.

108 See notes 87-95 supra and accompanying text.

106 See, e.g., United States v. Rosen, 353 F.2d 523 (2d Cir. 1965), cert. denied, 383 U.S. 908 (1966); United States v. Collins, 272 F.2d 650 (2d Cir. 1959), cert. denied, 362 U.S. 911 (1960); United States v. Parker, 244 F.2d 943 . (7th Cir.), cert. denied, 355 U.S. 836 (1957).

${ }^{205}$ See notes 31-32 supra and accompanying text.

${ }^{100}$ New York permits the prospective defendant to appear under certain circumstances but requires a waiver of immunity in exchange. Furthermore, under the New York rule, the accused must learn of the pending investigation on his own to take advantage of the appearance option. See note 19 supra.

Allowing the prospective defendant to appear in order to exonerate himself at an early date-thereby avoiding the expense and stigma of a full-fledged prosecutionwould also comport with the primary purpose of the grand jury. See notes 16-17 supra and accompanying text.

${ }^{107}$ See note 99 supra. Grand juries, with their broad subpoena power, are most effective in conducting investigations into suspected widespread criminal activities (e.g., antitrust violations, corruption in government) rather than isolated and individual criminal acts, and it is precisely in these instances where the ultimate defendauts are usually unknown at the outset. See, e.g., United States v. Bergman, 354 F.2d 931, 932-33 (2d Cir. 1966) (investigation of alleged "bribery, graft and other cor. ruption involving postal employees and mail contractors in the New York region'); United States v. Rosen, 353 F.2d 523 (2d Cir. 1965), cert. denied, 383 U.S. 908 (1966) (involving investigation into bribery, graft, extortion, and other corrupt practices
} 
further interrogation may introduce the spectres which the rule is designed to avoid.

(2) The evidence given by a witness before a grand jury may be excluded from governmental use against him where it is determined that under the circumstances he was entitled to the assistance of counsel but such assistance was denied. ${ }^{168}$ Although this rule would have the advantage of allowing the accused to clear himself at the onset of criminal involvement by personal appearance, its effectuation would involve many difficult elements of proof. First, the witness might have to show that the investigation had shifted from the "inquisitorial" to the "accusatorial" stage sometime before the harmful testimony was given. ${ }^{169}$ Second, and more importantly, he might have to demonstrate that the prosecution used the particular evidence obtained during the grand jury proceeding to procure other evidence against him, as opposed to the possibility that the secondary evidence was obtained from an independent source or different lead. ${ }^{170}$

(3) A witness, called to appear before a grand jury, may be afforded the right to assistance from counsel during his interrogation. ${ }^{171}$ Adoption of this rnle would have the distinct advantages of completely satisfying the guarantees of the fifth and sixth amendments while at the same time providing easy administration.

The effect which the extension of the right to counsel might have on the institution of the grand jury as an effective instrument of the criminal law, although difficult to ascertain in advance, would upon reflection appear to be negligible. It has already been noted that extension of this right would neither adversely affect the secret

allegedly involving FHA employees and local builders); United States v. Winter, 348 F.2d 204 (2d Cir.), cert. denied, 382 U.S. 955 (1965) (same). During the course of such investigations it unay be essential for the grand jury to call persons whose criminal responsibility is impossible to determine beforehand but who will eventually be charged. See Enker \& Elsen, supra note 120, at 74 .

${ }^{168}$ See notes 60-64 supra and accompanying text.

${ }^{180}$ See text accompanying note 153 supra; Enker \& Elsen, supra note 120 , at 73. In the event, however, that a grand jury interrogation is considered necessarily to constitute a "custodial interrogation" under Miranda, no showing of "accusatorial" propensity would appear to be necessary. See text accompanying note 155 supra.

${ }_{170}$ The right to have information or its fruits which are procured by the violation of constitutional rights excluded from evidence and from governmental consideration should be thought of exclusively as a remedial right. Where the practice which constituted the abridgment of the constitutional rights in question may be avoided altogther, such an alternative ought to be adopted. Suppression of illegal evidence is a poor substitute for the prohibition of its procurement.

${ }^{171}$ See notes 156-58 supra and accompanying text. 
nature of the proceedings ${ }^{172}$ nor result in undesirable delays. ${ }^{173}$ The only valid objection remaining is that the presence of counsel would interfere with the investigatory freedom of the grand jury or the prosecutor and thereby impede justice. ${ }^{174}$ This argument cuts both ways. To the extent that the free hand of the prosecutor is preserved, it must also be recognized that the witness may be the calculated target of its excesses. Nevertheless, in the final analysis, there is little reason to believe that the legitimate investigatory activities of the grand jury would be at all impaired by the extension of the right to counsel for the benefit of the witnesses.

${ }^{172}$ See note 120 supra and accompanying text.

${ }^{178}$ See note 119 supra and accompanying text.

174 See note 121 supra and accompanying text. 